$10-28-2015$

\title{
Modeling estuarine response to load reductions in a warmer climate: York River Estuary, Virginia, USA
}

Samuel J. Lake

Virginia Institute of Marine Science

Mark Brush

Virginia Institute of Marine Science

Follow this and additional works at: https://scholarworks.wm.edu/vimsarticles

Part of the Marine Biology Commons

\section{Recommended Citation}

Lake, Samuel J. and Brush, Mark, Modeling estuarine response to load reductions in a warmer climate: York River Estuary, Virginia, USA (2015). Marine Ecology Progress Series, 538, 81-98. doi: $10.3354 /$ meps 11448

This Article is brought to you for free and open access by the Virginia Institute of Marine Science at W\&M ScholarWorks. It has been accepted for inclusion in VIMS Articles by an authorized administrator of W\&M ScholarWorks. For more information, please contact scholarworks@wm.edu. 


\title{
Modeling estuarine response to load reductions in a warmer climate: York River Estuary, Virginia, USA
}

\author{
Samuel J. Lake*, Mark J. Brush \\ Virginia Institute of Marine Science, College of William \& Mary, PO Box 1346, Gloucester Point, Virginia 23062, USA
}

\begin{abstract}
The impact of climate warming on shallow tributary estuaries will be influenced by the complex cycling of nutrients and organic matter, diversity of primary producers, and enhanced benthic-pelagic coupling typical of these systems, along with advection of nutrients, organic matter, and hypoxic water from adjacent systems. This study utilized a parsimonious, reducedcomplexity model that combines mechanistic equations with robust, data-driven, empirical formulations to predict how phytoplankton net primary production (NPP), net ecosystem metabolism (NEM), and hypoxia will change under a range of warmer conditions in the York River Estuary, VA, USA, a sub-estuary of Chesapeake Bay. Modeled NPP peaked earlier and responded positively to warming in the winter and spring throughout most of the system due to increased rates of nutrient remineralization; NPP remained elevated during summer and fall in the upper estuary under warming but decreased in the lower estuary. These changes caused the upper estuary to become more autotrophic, while NEM decreased in the lower estuary due to greater stimulation of respiration relative to NPP. Warming increased the predicted temporal and spatial extent of hypoxia, with the upper estuary experiencing a relatively constant increase in the number of hypoxic days with increasing temperature. Hypoxia in the lower estuary increased more rapidly with temperature. Offsetting this increase in hypoxia with climate warming will require additional nutrient and organic matter load reductions from the surrounding watershed and Chesapeake Bay in order to achieve the same level of improvement predicted in the absence of a warming climate.
\end{abstract}

KEY WORDS: York River · Ecosystem model $\cdot$ Climate warming $\cdot$ Primary production $\cdot$ Net ecosystem metabolism $\cdot$ Hypoxia

Resale or republication not permitted without written consent of the publisher

\section{INTRODUCTION}

Estuaries are some of the most anthropogenically altered ecosystems worldwide, which is in large part due to their historical importance as maritime ports (Cooper \& Brush 1993, de Jonge et al. 1994, Cloern 2001, Boesch 2002). Many of the initial human impacts included direct alterations via deforestation, wetland drainage, river damming, water diversion, and channel dredging (Dynesius \& Nilsson 1994, Lotze 2010). During the early- and mid20th century, large-scale production and application of commercial fertilizer initiated the cultural eutrophication of marine systems in Europe, North America, and parts of Asia (Brush \& Davis 1984,
Nixon 1995, Richardson \& Heilmann 1995, Howarth \& Marino 2006, Brush 2009). From this period forward, coastal systems worldwide were directly influenced by continued pollution, and elevated rates of organic matter, nutrient, and sediment loading (Goldberg et al. 1978, Brush \& Davis 1984, Zimmerman \& Canuel 2000, Kemp et al. 2005). More recently, these systems have been subject to another more indirect human influence, a warming climate (Nixon et al. 2009, Smith et al. 2010, Doney et al. 2012). Over the past century, atmospheric temperatures have increased globally by $0.74^{\circ} \mathrm{C}$ (IPCC 2007), while mean ocean surface temperatures have increased by $0.31^{\circ} \mathrm{C}$ since 1950 (Levitus et al. 2000). 
The effect of a warming climate and the associated ecological responses are often difficult to quantify due to seasonal and interannual variability, as well as unrelated, concurrent ecological changes (Murdoch et al. 2000, Scavia et al. 2002, Oviatt 2004, Cloern \& Jassby 2008, Whitehead et al. 2009). The physical response of temperate estuaries to warming will likely result in higher rates of evaporation, reduced dissolved oxygen saturation, and seasonal changes in precipitation and stratification (Gibson \& Najjar 2000, Najjar et al. 2010, Cloern et al. 2011). These changes, together with enhanced metabolic rates due to elevated temperatures, will modify the cycling of nutrients and organic matter, and have the potential to alter the timing and community composition of phytoplankton blooms (Oviatt et al. 2002, Edwards \& Richardson 2004, Paerl \& Huisman 2008, 2009, Nixon et al. 2009, Canuel et al. 2012, Paerl \& Otten 2013). The effect of these ecological shifts is still largely unknown; however, it is likely that rates of primary production will change with warming temperatures, which have been cited as a potential factor causing the decline of the winter-spring phytoplankton bloom and reduced rates of annual primary production in Narragansett Bay, RI (Oviatt et al. 2002, Nixon et al. 2009). However, the system-level response is complex and will likely vary between systems (Canuel et al. 2012, Doney et al. 2012).

Increasing temperatures also have the potential to decrease net ecosystem metabolism (NEM = production - respiration) and enhance the degree of net heterotrophy in coastal systems given the strong dependence of pelagic and sediment respiration on temperature (Caffrey 2004, Hopkinson \& Smith 2005) and the greater sensitivity of respiration to temperature compared to production (López-Urrutia et al. 2006, O'Connor et al. 2009). O'Connor et al. (2009) demonstrated that increasing temperature could result in increased primary productivity, decreased total biomass, stronger consumer control, and a shift in pelagic food web structure. However, this response was limited to nutrient-enriched treatments, indicating an interaction between enrichment and temperature.

Warming temperatures also have the potential to complicate ongoing efforts to restore estuaries through nutrient load reductions (e.g. US EPA 2010, Moss et al. 2011, Meier et al. 2012, Neumann et al. 2012). This may be especially true in the relatively shallow tributary estuaries that flow into Chesapeake Bay (CB), including the York River Estuary (YRE) (Fig. 1). The response of tributary estuaries to a warming climate will likely be complicated given the complex cycling of nutrients, the presence of extensive photic shoals - which leads to enhanced benthic-pelagic coupling and benthic primary production by microphytobenthos (MPB) - and the importance of allochthonous inputs of labile organic matter from the watershed and via estuarine circulation (Boynton et al. 1995, Testa et al. 2008, Lake et al. 2013). The development of hypoxia in the YRE has been linked to both watershed nutrient inputs and the advection of water rich in nutrients and organic matter from the mainstem $\mathrm{CB}$, along with variable physical mixing processes (Haas 1977, Kuo \& Neilson 1987, Sharples et al. 1994). A recent analysis indicated that different regions of the YRE will require different management efforts to reduce hypoxia, with localized watershed load reductions improving conditions up-estuary and more regionally driven reductions from CB having the greatest impact in the lower estuary (Lake \& Brush 2015). Given the many potential impacts of climatic warming on metabolic rate processes, it is likely that external load reductions will need to be increased to achieve the same level of improvement under a warming climate.

The purpose of the present study was to utilize a parsimonious, reduced-complexity model recently developed for the YRE (Fig. 2) to predict the effect of climate warming on the ecosystem. The specific objectives were to: (1) examine how primary production and respiration respond to warmer climate conditions, (2) quantify temporal and spatial changes in hypoxia, and (3) expand the previous analysis of external load reductions to include the interactive effects of these reductions with a warming climate. While the effect of climate change on the YRE will not be limited to increasing temperatures, but will also include effects of increased precipitation, storminess, and sea level rise (Najjar et al. 2010), our purpose here is to begin with the first-order effect of temperature and its interactions with external loading on ecosystem function and development of hypoxia.

\section{METHODS}

\section{Site description}

The YRE was divided into a series of 8 boxes along the axis (Fig. 1, Table 1). These regions were designated based on long-term water quality monitoring by the US Environmental Protection Agency (EPA) Chesapeake Bay Program (CBP) and the presence of hypoxia during monitoring surveys (see Lake et al. 


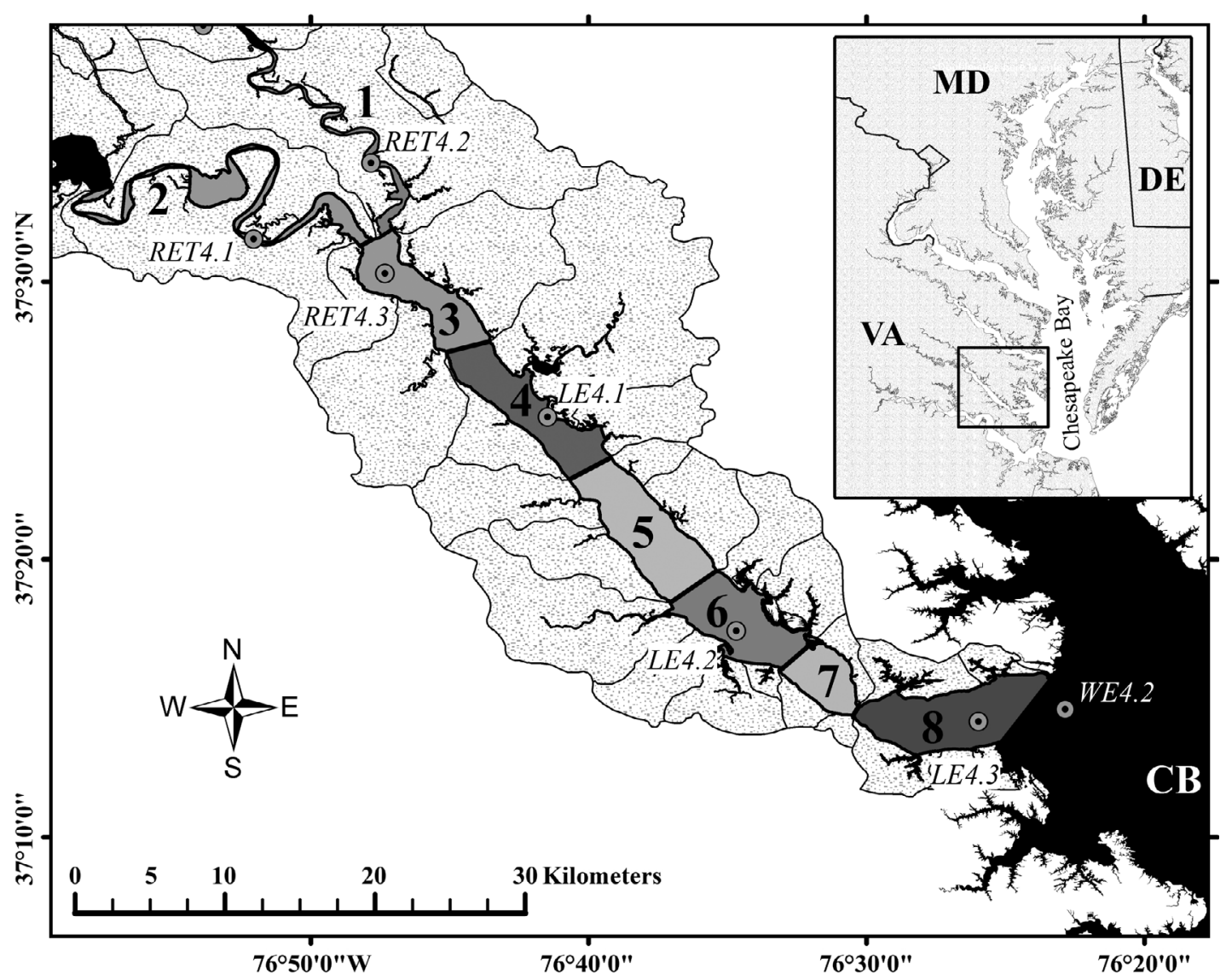

Fig. 1. Map of the York River Estuary and Chesapeake Bay ( $\mathrm{CB}_{\text {; }}$ inset), including box model boundaries, small ungauged watersheds, and corresponding long-term Chesapeake Bay Program monitoring stations (points RET4.1, RET4.2, RET4.3, LE4.1, LE4.2, LE4.3 and WE4.2). Upper estuary Boxes 1 and 2 are located within the 2 tributaries, and Boxes 3 and 4 are located below the confluence in the low-mesohaline region. Lower estuary Boxes 5 and 6 are located in the high-mesohaline region, and Boxes 7 and 8 are in the polyhaline portion of the estuary

2013). The 2 upstream oligohaline sites (Boxes 1 and 2) are located within the lower Mattaponi and Pamunkey Rivers, respectively. Boxes 3 and 4 are located in the low-mesohaline region, while Boxes 5 and 6 are located in the high-mesohaline portion of the estuary, which is typically characterized as having little to no signs of hypoxia. The 2 downstream polyhaline regions (Boxes 7 and 8) are subject to periodic hypoxia throughout the summer (Kuo \& Neilson 1987, Kuo et al. 1993, Lake et al. 2013).

Table 1. Spatial dimensions of box model segments in the York River Estuary. All area $\left(\mathrm{m}^{2}\right)$ and volume $\left(\mathrm{m}^{3}\right)$ values are expressed $\times 10^{6}$. All values are relative to mean sea level

\begin{tabular}{|c|c|c|c|c|c|c|c|c|c|c|}
\hline \multirow[b]{2}{*}{ Box } & \multirow[b]{2}{*}{$\begin{array}{l}\text { Surface } \\
\text { area } \\
\left(\mathrm{m}^{2}\right)\end{array}$} & \multirow[b]{2}{*}{$\begin{array}{l}\text { Volume } \\
\qquad\left(\mathrm{m}^{3}\right)\end{array}$} & \multirow[b]{2}{*}{$\begin{array}{l}\text { Mean } \\
\text { depth } \\
(\mathrm{m})\end{array}$} & \multirow[b]{2}{*}{$\begin{array}{l}\text { Pycnocline } \\
\text { depth } \\
\text { (m) }\end{array}$} & \multicolumn{3}{|c|}{ Above pycnocline } & \multicolumn{3}{|c|}{ Below pycnocline } \\
\hline & & & & & $\begin{array}{l}\text { Sediment } \\
\text { area } \\
\left(\mathrm{m}^{2}\right)\end{array}$ & $\begin{array}{l}\text { Volume } \\
\left(\mathrm{m}^{3}\right)\end{array}$ & $\begin{array}{l}\text { Mean } \\
\text { depth } \\
(\mathrm{m})\end{array}$ & $\begin{array}{l}\text { Sediment } \\
\text { area } \\
\left(\mathrm{m}^{2}\right)\end{array}$ & $\begin{array}{l}\text { Volume } \\
\left(\mathrm{m}^{3}\right)\end{array}$ & $\begin{array}{l}\text { Mean } \\
\text { depth } \\
(\mathrm{m})\end{array}$ \\
\hline 1 & 4.3 & 11.9 & 2.7 & 4.0 & 3.4 & 10.4 & 2.4 & 0.9 & 1.5 & 5.6 \\
\hline 2 & 8.7 & 24.9 & 2.9 & 4.0 & 6.5 & 22.4 & 2.6 & 2.2 & 2.6 & 5.2 \\
\hline 3 & 20.9 & 51.6 & 2.5 & 5.0 & 17.5 & 47.1 & 2.3 & 3.4 & 4.4 & 6.3 \\
\hline 4 & 24.3 & 81.4 & 3.4 & 5.0 & 16.9 & 67.2 & 2.8 & 7.4 & 14.2 & 6.9 \\
\hline 5 & 31.1 & 105.7 & 3.4 & 5.0 & 24.3 & 92.2 & 3.0 & 6.8 & 13.6 & 7.0 \\
\hline 6 & 24.9 & 107.1 & 4.3 & 5.0 & 15.9 & 69.6 & 2.8 & 9.0 & 37.5 & 9.2 \\
\hline 7 & 11.6 & 80.3 & 6.9 & 9.0 & 7.0 & 60.1 & 5.2 & 4.6 & 20.1 & 13.4 \\
\hline 8 & 33.2 & 236.6 & 7.1 & 9.0 & 20.6 & 179.2 & 5.4 & 12.6 & 57.4 & 13.6 \\
\hline
\end{tabular}




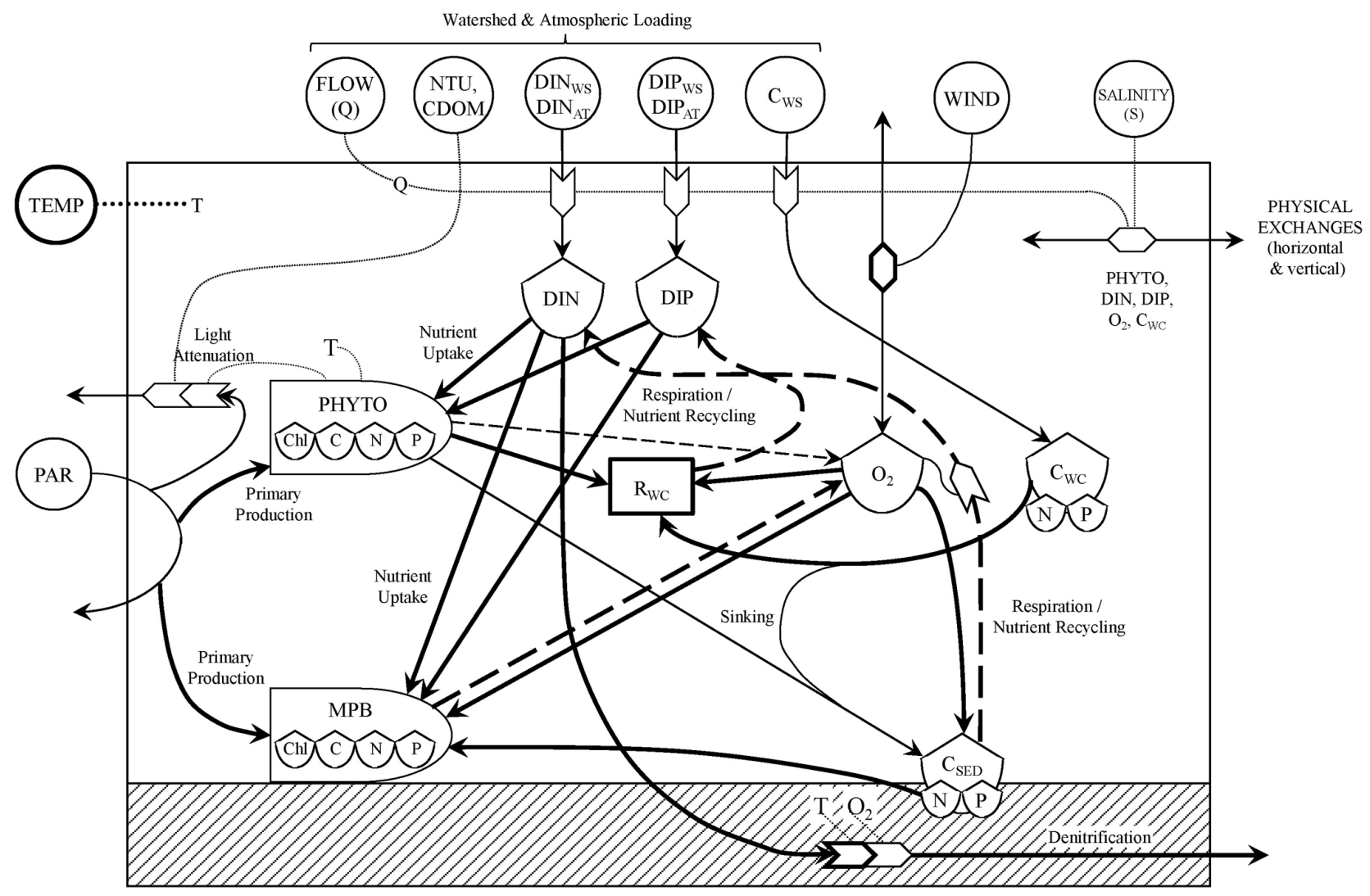

Fig. 2. Diagram of the reduced-complexity eutrophication model. State variables, major flows (with arrows), and major connections (without arrows) are depicted. Flows that consume material (e.g. nutrient uptake, oxygen consumption, loss of biomass) are shown with solid lines. Flows that produce material (e.g. remineralization, photosynthetic oxygen production) are shown with dashed lines. Bold lines and symbols highlight variables (and rates) that are temperature dependent. To reduce the complexity of the figure, all respiratory demands are shown as being integrated into an estimate of total water column respiration $\left(\mathrm{R}_{\mathrm{WC}}\right)$, which draws from the oxygen pool and remineralizes $\mathrm{N}$ and P. WS: watershed; AT: atmospheric. All other terms are defined in the section 'Reduced-complexity eutrophication model'. Symbols are those of Odum (1994). Adapted from Brush (2002) and Lake \& Brush (2015)

\section{Linkage between air and water temperature}

Current predictions of temperature increases for the $\mathrm{CB}$ region are for air (i.e. $1.1^{\circ} \mathrm{C}$ by $2039,2.3^{\circ} \mathrm{C}$ by 2069 , and $3.9^{\circ} \mathrm{C}$ by 2100 ; Najjar et al. 2009). While Najjar et al. (2010) did not directly estimate the effect that increasing air temperatures would have on water temperatures, they noted a positive correlation between water temperatures in CB and regional atmospheric and ocean temperatures measured in previous studies, and suggested that these climate model projections could be applied directly to CB. To further assess this relationship, measurements made in the lower $\mathrm{CB}$ and throughout the YRE were used to develop regressions relating air temperatures to surface and bottom water temperatures for use in the model. CB water temperature measurements from 1949 to 1982 and 1984 to 2012 were downloaded from the CBP website (www.chesapeakebay.net). Measurements made in the polyhaline CB from 1949 to 1982 were organized into 2 depth segments: surface water and bottom water. Similarly, measurements from 1984 to 2012 were sorted into surface and bottom measurements for the polyhaline CB and YRE box model regions 1-3 and 4-8. These water temperature measurements were then paired with mean monthly air temperature measurements from Norfolk International Airport, downloaded from the NOAA National Climatic Data Center (www.ncdc.noaa.gov/ oa/ncdc.html).

\section{Reduced-complexity eutrophication model}

Lake \& Brush (2015) adapted a model to the YRE that combines the benefits of both empirical and 
mechanistic modeling approaches into a reducedcomplexity, shallow marine ecosystem model (Brush 2002, 2004, Brush et al. 2002, Brush \& Brawley 2009). This approach includes only those state variables and rate processes of primary importance to the process of estuarine eutrophication, and integrates robust empirical relationships that have been shown to apply across a wide range of temperate estuaries to predict key rate processes. State variables include the biomass of phytoplankton and MPB simulated in carbon $(\mathrm{C})$ units, with nitrogen $(\mathrm{N})$, phosphorus $(\mathrm{P})$, and chlorophyll a (chl a) biomass computed stoichiometrically, water column pools of labile organic carbon $\left(\mathrm{C}_{\mathrm{WC}}\right)$ and its associated $\mathrm{N}$ and $\mathrm{P}$, dissolved inorganic nitrogen (DIN) and phosphorus (DIP), dissolved oxygen (DO or $\mathrm{O}_{2}$ ), and the pool of recently deposited, labile organic carbon in the sediments $\left(\mathrm{C}_{\mathrm{SED}}\right)$ and its associated nitrogen and phosphorus (Fig. 2). The model was applied to the YRE from January 2007 to December 2010, using a time step of $90 \mathrm{~min}(\mathrm{~d} t=$ 0.0625 d). Full details regarding model formulations and specific calibration to the YRE can be found in Lake \& Brush (2015) and related publications (Brush 2002, 2004, Brush et al. 2002, Brush \& Brawley 2009). The following paragraphs briefly outline the major components of the model and highlight the key processes that are temperature-dependent given the focus of this paper on climatic warming; these have been highlighted in Fig. 2 and are summarized in Tables S1 and S2 in the Supplement (see www.intres.com/articles/suppl/m538p081_supp.pdf).

Phytoplankton biomass is simulated as a single aggregated pool, with net primary production (NPP; net organic matter production by autotrophic organisms) computed using a temperature-dependent version of a 'light $\times$ biomass' (BZI) model (see Brush et al. 2002, Brush \& Brawley 2009). The benefit of this approach is that the empirical BZI models are rooted in direct measurements $\left({ }^{14} \mathrm{C}\right)$ of productivity that have been shown to apply across a wide range of systems, and produce predicted rates directly comparable to observations (i.e. $\mathrm{g} \mathrm{C} \mathrm{m} \mathrm{C}^{-1}$ rather than growth rates). The potential rate of NPP predicted by the BZI formulation is limited by the availability of DIN and DIP at each time step. Phytoplankton biomass is lost to physical exchanges and heterotrophic processes within the water column and sediments; the latter are exponential functions of temperature. In an effort to reduce model uncertainty and eliminate loosely constrained parameters, a single aggregated term for pelagic heterotrophic consumption was utilized, which computes planktonic community respiration (PCR) as a function of temperature and moving-average chl a biomass. This term incorporates phytoplankton respiration, planktonic grazing, and subsequent respiration by the grazer and microbial community, ties the rate of PCR to two of its dominant controls (i.e. temperature and chl a; Hopkinson $\&$ Smith (2005), and utilizes the moving average chl a biomass to incorporate lag times typical of heterotrophic processes. An empirically based, system-level relationship between annual sediment carbon remineralization and total annual carbon input from primary production and allochthonous inputs was used to estimate the flux of organic carbon reaching the sediment surface (Nixon 1986). Respiration of this labile carbon pool is driven as an exponential function of temperature.

MPB are simulated with a recently developed submodel (Lake \& Brush 2015), where MPB production and respiration are simulated as a function of temperature and irradiance at depth. Nutrient limitation was not included since MPB have the ability to obtain nutrients from overlying water as well as pore water within the sediments. Respiratory consumption of allochthonous organic matter inputs follows the same temperature dependence as PCR. All production and respiration functions described above stoichiometrically produce or consume DO, DIN, and DIP, so these cycling rates are also dependent on temperature. Potential denitrification rates were computed as a temperature-dependent fraction of the modeled DIN concentration. This potential denitrification rate was reduced using a denitrification efficiency function under low oxygen conditions to account for a reduction in coupled nitrification-denitrification and the resulting increase in the release of $\mathrm{NH}_{4}{ }^{+}$, as described by Lake \& Brush (2015). Modeled denitrification rates were calibrated to measurements made in multiple CB tributaries including the YRE (Kana et al. 1998, 2006, Boynton et al. 2008, Cornwell \& Owens 2011). Finally, air-sea diffusion of oxygen is computed as a function of wind speed and the concentration at saturation, which is in turn a function of water temperature and salinity.

The ecosystem model is coupled to an Officer (1980) 2-layer box model, which computes both gravitational circulation (advective) and tidal (nonadvective) volumetric exchanges among the spatial elements as a function of forced salinity and freshwater inputs. The model was implemented in 8 boxes along the axis of the estuary as described above, each with a surface and bottom layer. While box models necessarily lose spatial resolution compared to higher resolution 3-D hydrodynamic models, they nonetheless reproduce typical down-estuary and sur- 
face-to-bottom gradients, operate at the typical scale of available monitoring data (e.g. Fig. 1), are driven by exchanges that are constrained by observations, and enable fast run times, which makes possible the multiple runs required for adequate calibration, sensitivity analysis, and forecasting scenarios. Recent work has confirmed the utility of boxed approaches (Ménesguen et al. 2007, Testa \& Kemp 2008, Kremer et al. 2010).

An extensive sensitivity analysis was conducted on the original version of the model by varying all parameters $\pm 20 \%$ or within typical ranges (Brush 2002). Results indicated sensitivity, defined as median percent change in state variables by $10 \%$ or more relative to the calibration run, to a limited number of parameters, including the $\mathrm{C}: \mathrm{chl}$ a ratio, intercept of the relationship between temperature and slope of the BZI function, zero degree intercept and exponent of the relationship between temperature and water column respiration, fraction of NPP deposited to the sediments, averaging time for freshwater inputs in the Officer box model, and averaging time for phytoplankton biomass in the calculation of pelagic heterotrophic processes. Changes in C:chl a produced changes to simulated chl a biomass by $37 \%$; other parameters affected various aspects of model output by $10-18 \%$, but no parameters affected predicted oxygen concentrations by more than $10 \%$. All but the last parameter were either constrained by available data or were constrained during the current calibration to match observed rate processes (e.g. water column respiration).

\section{Climate simulations}

The calibrated run of the model between January 2007 and December 2010 under current conditions (CC) from Lake \& Brush (2015) was used as a baseline comparison for all subsequent climate simulations. A range of potential warming scenarios $(+1,2$, 3 and $5^{\circ} \mathrm{C}$ year-round) were then simulated, rather than running specific temperature projections, in an effort to capture the potential ecological changes that might occur across this range of warming. This range brackets multi-model climate projections for the MidAtlantic under enhanced greenhouse gas concentrations, up to the end of the century (Najjar et al. 2009). Predicted YRE response to a warming climate was quantified as changes in phytoplankton NPP, NEM (the difference between modeled water column and MPB production, and water column and sediment respiration occurring within each box, surface and bottom layers combined), and the frequency and extent of hypoxia for each box.

Once the effect of warmer climate conditions was quantified, model runs were conducted to determine how future reductions in nutrient and organic matter loading from the Mattaponi and Pamunkey Rivers, smaller ungauged basins surrounding the YRE proper, and $\mathrm{CB}$ would influence the development of hypoxia under a warming climate. Simulations focused on decreasing these sources by $5,10,15,25$, and $50 \%$ relative to current conditions and were conducted over the same range of temperature increases as above $\left(+1,2,3\right.$, and $\left.5^{\circ} \mathrm{C}\right)$. While independent simulations for warming and source loading were not examined in this study, it is likely that there is an interactive effect between these various treatments. Rates, concentrations, and the number of hypoxic days from the 4-yr simulations were averaged to account for interannual variability.

\section{RESULTS AND DISCUSSION}

\section{Linkage between air and water temperature}

Our analysis confirmed that atmospheric temperatures can be used to estimate surface and bottom water temperatures in the $\mathrm{CB}$ and YRE with an approximately 1:1 correspondence (Fig. 3), at least within the range of recent atmospheric conditions, as suggested by Najjar et al. (2010). Future climate change may alter the linkage between air and water temperatures due to a number of potential feedbacks including changes in wind speed and duration, and increased density stratification resulting from elevated freshwater delivery. Some of these processes have been suggested as important factors modulating oxygen conditions in other climate modeling studies (Meier et al. 2011, 2012, Bruce et al. 2014). However, since a more detailed relationship based on hydrodynamic models is not available for the CB and its tributary estuaries, the present study utilized these strong positive correlations for all climate scenarios.

\section{Model skill}

Lake \& Brush (2015) calibrated the model to available observations from 2007 to 2010. Model predictions of phytoplankton chl a and DO followed the measurements made by the CBP within all boxes, throughout all 4 years (Fig. $4 \mathrm{a}-\mathrm{C}$ and $\mathrm{g}-\mathrm{i}$, respec- 

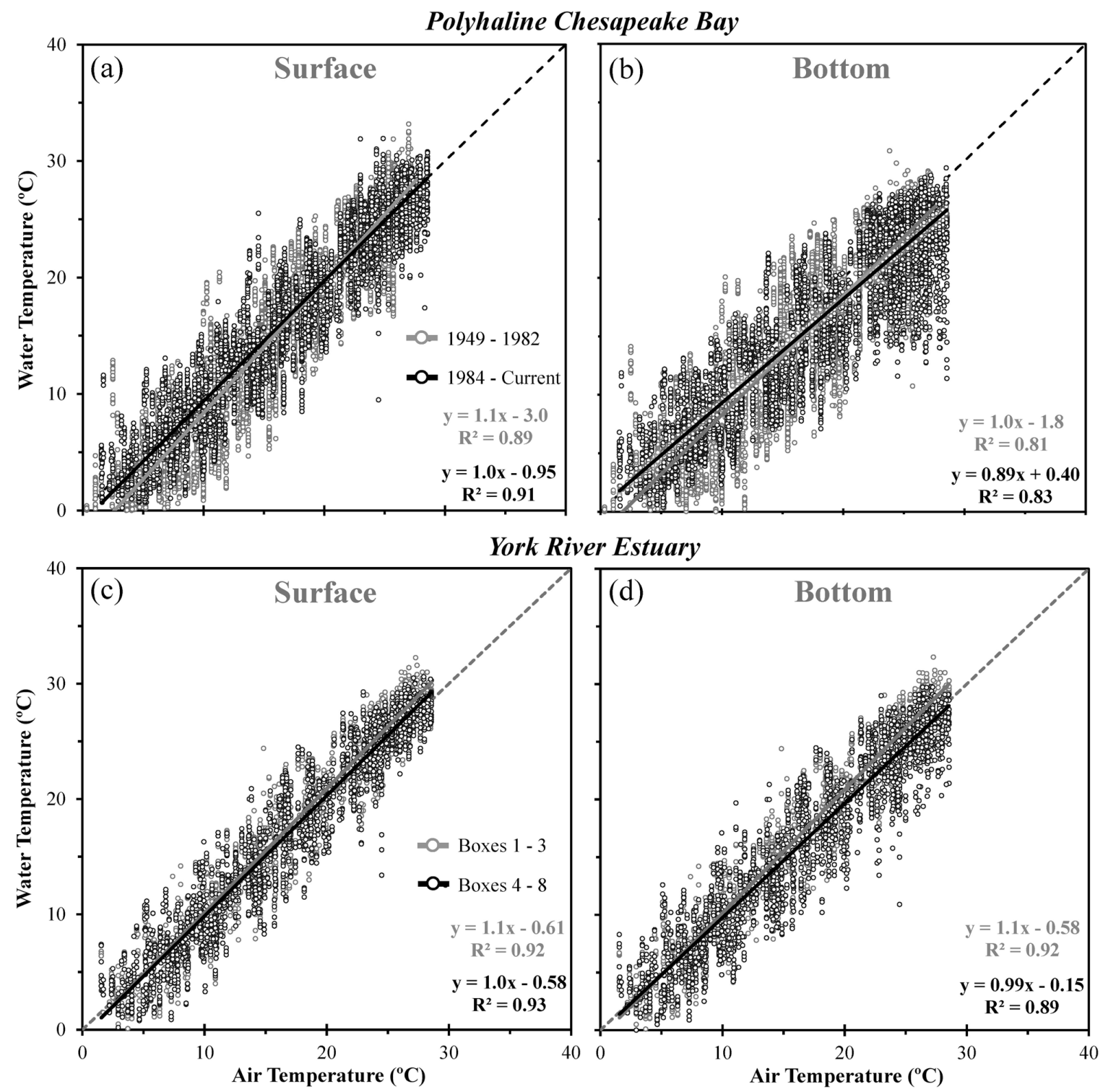

Fig. 3. Polyhaline Chesapeake Bay (a) surface and (b) bottom water temperatures (Chesapeake Bay Program, CPB) plotted against mean monthly air temperatures measured at Norfolk International Airport, between 1949 and 1982 , and 1984 and 2012. York River Estuary (c) surface and (d) bottom water temperatures at CBP sites located in Boxes 1-3 and 4-8 from 1984 to 2012, plotted against mean monthly air temperatures measured at Norfolk International Airport

tively). The percent error observed between measured chl a concentrations and modeled values was relatively low for the system as a whole $(11.2 \%)$, and lower for Boxes 5-8 (5.4\%), where hypoxia occurs. The model captured the seasonal cycle of DO, along with shorter-term oscillations measured during the summers of 2007 and 2008 using an Acrobat ${ }^{\mathrm{TM}}$ tow body (Sea Sciences, Inc.). Acrobat ${ }^{\mathrm{TM}}$ sensors collected spatially referenced water quality data 4 times per second with a horizontal resolution of $6-8 \mathrm{~m}$ and a vertical resolution of 5-10 cm, for a total of $40000-$ 50000 data scans per survey. Additional sampling and calibration details can be found in Lake et al. (2013). The absolute error associated with bottom water DO in Boxes 5-8 was less than $0.5 \mathrm{mg} \mathrm{O} \mathrm{O}^{-1}$ (0.33). Modeled DIN concentrations were within the range of measurements made by the CBP and followed the overall seasonal cycles (Fig. $4 \mathrm{~d}-\mathrm{f}$ ). The absolute error between modeled and measured surface water concentrations was less than $0.05 \mathrm{~g} \mathrm{~m}^{-3}$. Predicted phytoplankton NPP was within the range of values from metabolic experiments conducted in 2008 (Lake et al. 2013) and previous studies in the CB (Smith \& Kemp 1995, Harding et al. 2002), although the model slightly underestimated some of the higher rates measured in Boxes 7 and 8 (Fig. 4k,l). Surface water respiration was also within the range of rates from Lake et al. (2013) for Boxes 5 and 6, and within 

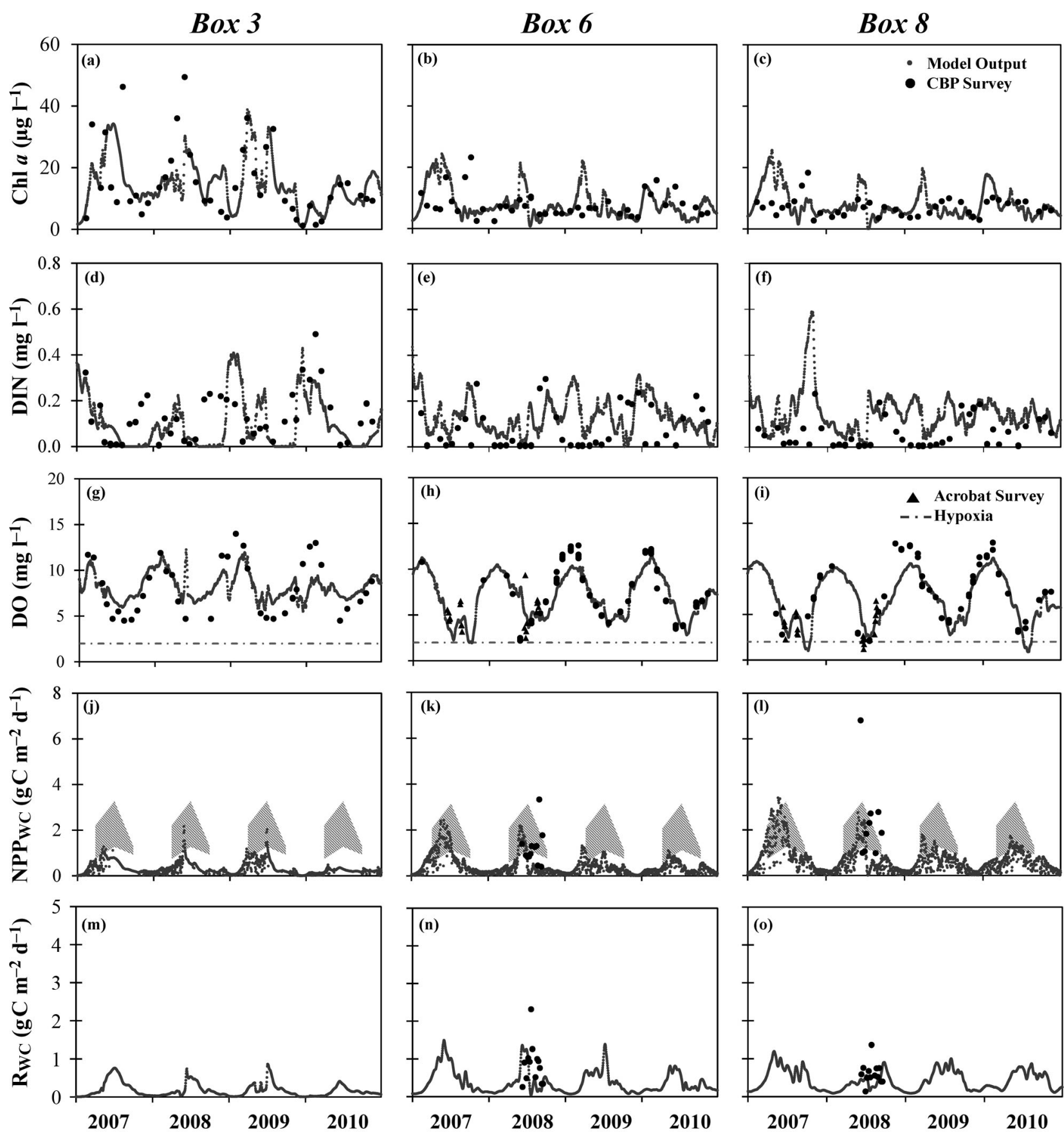

Fig. 4. Measured (large black points, Chesapeake Bay Program [CBP]) and modeled (small gray points) (a-c) surface column chlorophyll a $(\mathrm{Chl} \mathrm{a}),(\mathrm{d}-\mathrm{f})$ surface dissolved inorganic nitrogen (DIN), (g-i) bottom dissolved oxygen (DO), and rates of (j-l) phytoplankton net primary production $\left(\mathrm{NPP}_{\mathrm{WC}}\right)$ and $(\mathrm{m}-\mathrm{o})$ bottom water column respiration $\left(\mathrm{R}_{\mathrm{WC}}\right)$. Volume-weighted DO concentrations sampled during the 2007 and 2008 Acrobat surveys are included as triangles in g-i (see Lake et al. 2013). Dashed lines in $\mathrm{g}-\mathrm{i}$ represent hypoxic conditions $\left(<2 \mathrm{mg} \mathrm{O}_{2} \mathrm{l}^{-1}\right)$. (j-l) Hashed areas represent the range of published seasonal phytoplankton production rates measured in the lower Chesapeake Bay (CB). Upper range: daytime net community production from Smith \& Kemp (1995); lower range: daily ${ }^{14}$ C production from Harding et al. (2002)

the lower range for Boxes 7 and 8. Bottom water respiration rates (Fig. 4m-o) and shoal and deep channel sediment respiration rates were all within the range of rates from Lake et al. (2013), with an absolute error of $0.09,0.09$, and $0.04 \mathrm{~g} \mathrm{C} \mathrm{m}^{-2} \mathrm{~d}^{-1}$, respectively. Deep channel sediment respiration rates overlapped the range reported by Cowan \& Boynton (1996) for the lower CB. Additional details related to model calibration and skill assessment can be found in Lake \& Brush (2015). 


\section{Predicted ecosystem function under a warmer climate}

Temporal changes in phytoplankton NPP

This analysis focused on simulated changes in phytoplankton rather than MPB NPP, since a recent budget indicated that phytoplankton are typically responsible for more than $90 \%$ of primary productivity in the YRE during summer (Lake et al. 2013), which is similar to the phytoplankton contribution for the mainstem Chesapeake Bay (Kemp et al. 2005). Simulated phytoplankton NPP displayed differing responses with respect to season and location under warmer temperatures. First, NPP was predicted to increase during the winter (December - February) and spring (March-May) throughout most of the estuary under all elevated temperature scenarios (Fig. 5a,b, Table 2). The increase in winter-spring production throughout the YRE was a response of not only temperature-dependent NPP, but also higher phytoplankton biomass and increased respiratory rates that led to higher surface water nutrient concentrations through remineralization of labile organic matter. These results are similar to those from other recent modeling studies in the Baltic Sea that reported an intensification of internal nutrient cycling, blooms, and primary production resulting from increased loading rates and temperature-dependent biochemical rate processes under future climate scenarios (Meier et al. 2011, 2012, Neumann et al. 2012). Second, the upper estuary (Boxes 1-3) continued to display increased phytoplankton NPP with increasing temperature during the summer and fall, while rates of NPP in the middle and lower estuary (Boxes 4-5 and 6-8, respectively) decreased with increasing temperature (Fig. 5c,d, Table 2).

Model simulations also indicated a temporal shift of maximum spring phytoplankton NPP and chl a concentrations when temperatures were raised above $+1^{\circ} \mathrm{C}$, where the spring bloom began 2 wk earlier under the $+5^{\circ} \mathrm{C}$ scenario in the upper estuary compared to current conditions. This response was a result of increased production earlier in the spring due to warmer temperatures, and a negative feedback in May as warmer temperatures increased simulated pelagic heterotrophic consumption, which includes both respiration and grazing. Lewandowska \& Sommer (2010) noted a similar result using mesocosms to investigate the effects of climate warming and light availability on phytoplankton, where phytoplankton blooms began approximately 1 wk earlier under warmer temperatures $\left(+6^{\circ} \mathrm{C}\right)$ compared to ambient conditions. These authors also reported a similar response using monitoring data from the western Baltic Sea, in which spring blooms occurred 1 to 2 wk earlier following warmer winters. Warming temperatures have also been cited as a potential factor causing the decline of the typical winter-spring phytoplankton bloom and reduced rates of annual primary production in Narragansett Bay, RI (Oviatt et
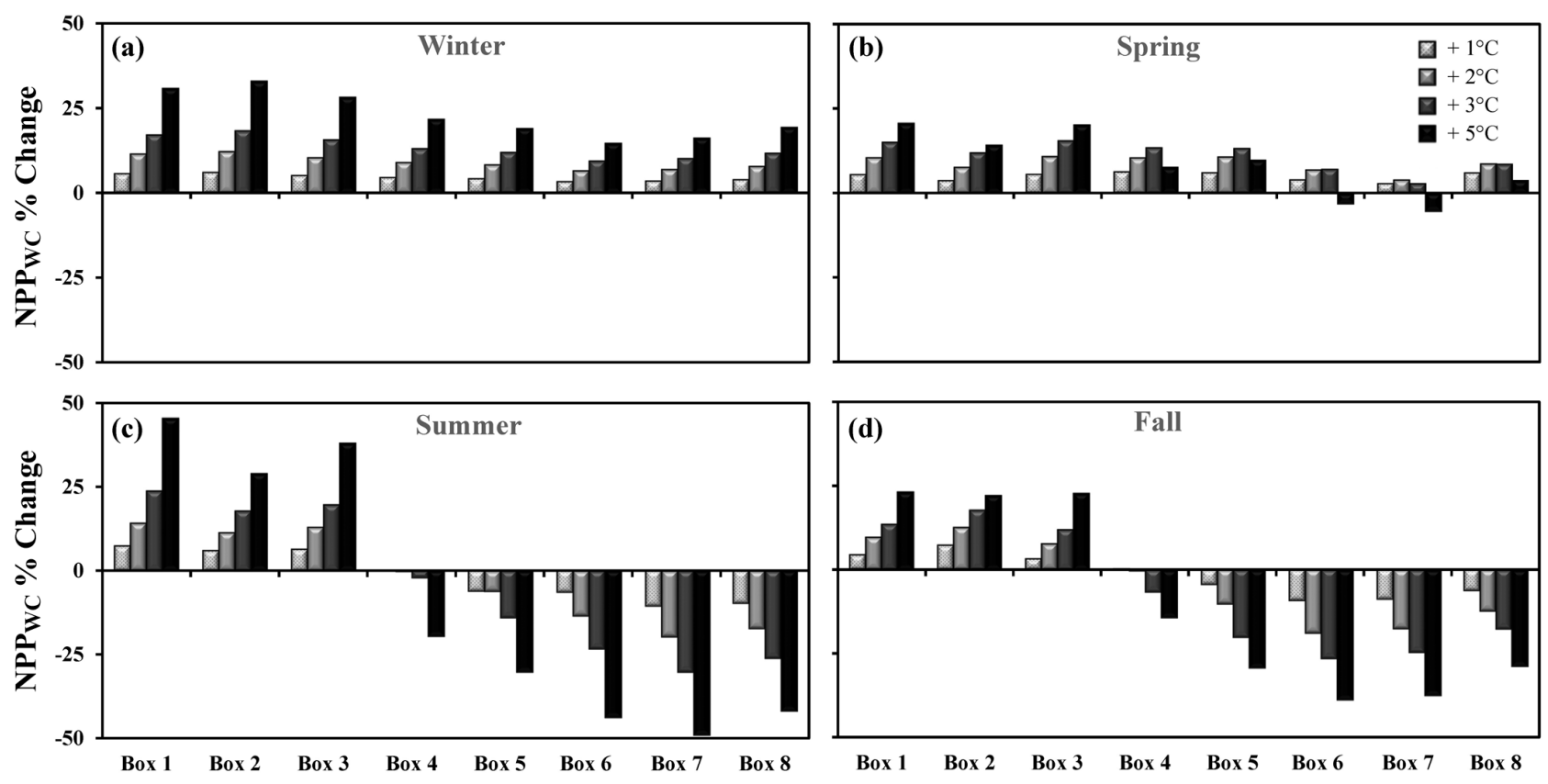

Fig. 5. Modeled percent change in daytime phytoplankton net primary production $\left(\mathrm{NPP}_{\mathrm{WC}}\right)$ relative to the baseline model simulation under a series of scenarios with increasing temperatures. Results were averaged over the 4-yr simulation 
Table 2. Modeled estimates of phytoplankton net primary production for 4 regions in the York River Estuary. Seasonal means and ranges (parentheses) are in $\mathrm{g} \mathrm{C} \mathrm{m}^{-2} \mathrm{~d}^{-1}$. Seasonal values are reported for winter (December to February), spring (March to May), summer (June to August) and fall (September to November). CC: current conditions

\begin{tabular}{|c|c|c|c|c|c|c|c|c|c|}
\hline \multirow[b]{2}{*}{$\mathrm{CC}$} & \multirow[b]{2}{*}{ Winter } & \multicolumn{2}{|c|}{ Oligohaline } & \multicolumn{2}{|c|}{ Low mesohaline } & \multicolumn{2}{|c|}{ High mesohaline } & \multicolumn{2}{|c|}{ Polyhaline } \\
\hline & & 0.05 & $(0.00-0.39)$ & 0.13 & $(0.00-0.49)$ & 0.16 & $(0.00-0.68)$ & 0.21 & $(0.00-0.79)$ \\
\hline & Spring & 0.17 & $(0.00-1.21)$ & 0.51 & $(0.02-2.17)$ & 0.64 & $(0.03-2.43)$ & 0.88 & $(0.04-3.64)$ \\
\hline & Summer & 0.55 & $(0.08-1.82)$ & 0.68 & $(0.10-2.19)$ & 0.85 & $(0.03-2.57)$ & 0.88 & $(0.00-3.34)$ \\
\hline & Fall & 0.28 & $(0.00-1.25)$ & 0.26 & $(0.00-0.75)$ & 0.36 & $(0.00-1.35)$ & 0.37 & (0.01-0.99) \\
\hline \multirow[t]{4}{*}{$+1^{\circ} \mathrm{C}$} & Winter & 0.05 & $(0.00-0.43)$ & 0.14 & $(0.00-0.52)$ & 0.17 & $(0.00-0.72)$ & 0.22 & $(0.00-0.83)$ \\
\hline & Spring & 0.17 & $(0.00-1.24)$ & 0.54 & $(0.02-2.25)$ & 0.67 & $(0.03-2.60)$ & 0.92 & $(0.05-3.72)$ \\
\hline & Summer & 0.58 & $(0.06-1.88)$ & 0.69 & $(0.08-2.33)$ & 0.79 & $(0.00-2.57)$ & 0.79 & $(0.00-3.48)$ \\
\hline & Fall & 0.30 & $(0.00-1.35)$ & 0.27 & $(0.00-0.79)$ & 0.33 & $(0.00-1.12)$ & 0.34 & $(0.01-0.84)$ \\
\hline \multirow[t]{4}{*}{$+2^{\circ} \mathrm{C}$} & Winter & 0.05 & $(0.00-0.47)$ & 0.14 & $(0.00-0.56)$ & 0.17 & $(0.00-0.77)$ & 0.23 & $(0.00-0.87)$ \\
\hline & Spring & 0.18 & $(0.00-1.44)$ & 0.56 & $(0.02-2.23)$ & 0.70 & $(0.03-2.81)$ & 0.94 & $(0.05-3.65)$ \\
\hline & Summer & 0.61 & $(0.04-2.02)$ & 0.70 & $(0.00-2.43)$ & 0.77 & $(0.00-2.66)$ & 0.72 & $(0.00-3.63)$ \\
\hline & Fall & 0.32 & $(0.00-1.38)$ & 0.27 & $(0.00-0.84)$ & 0.31 & $(0.00-1.19)$ & 0.31 & $(0.01-0.81)$ \\
\hline \multirow[t]{4}{*}{$+3^{\circ} \mathrm{C}$} & Winter & 0.06 & $(0.00-0.51)$ & 0.15 & $(0.00-0.60)$ & 0.18 & $(0.00-0.82)$ & 0.24 & $(0.00-0.91)$ \\
\hline & Spring & 0.19 & $(0.00-1.51)$ & 0.58 & $(0.02-2.54)$ & 0.71 & $(0.03-2.88)$ & 0.93 & (0.05-3.68) \\
\hline & Summer & 0.65 & $(0.03-2.09)$ & 0.71 & $(0.00-2.75)$ & 0.69 & $(0.00-3.20)$ & 0.63 & $(0.00-3.74)$ \\
\hline & Fall & 0.33 & $(0.00-1.43)$ & 0.26 & $(0.00-0.87)$ & 0.28 & $(0.00-1.20)$ & 0.29 & $(0.01-0.76)$ \\
\hline \multirow[t]{4}{*}{$+5^{\circ} \mathrm{C}$} & Winter & 0.06 & $(0.00-0.62)$ & 0.16 & $(0.00-0.69)$ & 0.19 & $(0.00-0.92)$ & 0.25 & $(0.00-0.99)$ \\
\hline & Spring & 0.20 & $(0.00-1.72)$ & 0.58 & $(0.01-2.33)$ & 0.67 & $(0.00-2.97)$ & 0.87 & (0.04-3.56) \\
\hline & Summer & 0.73 & $(0.01-2.85)$ & 0.68 & $(0.00-2.88)$ & 0.54 & $(0.00-3.36)$ & 0.48 & $(0.00-3.42)$ \\
\hline & Fall & 0.35 & $(0.00-1.48)$ & 0.26 & $(0.00-0.91)$ & 0.24 & $(0.00-1.21)$ & 0.25 & (0.01-0.68) \\
\hline
\end{tabular}

al. 2002, Nixon et al. 2009). Additionally, a recent modeling analysis for the Baltic Sea indicated that cyanoplankton blooms in the summer occurred 10-20 d earlier under warmer temperatures (Neumann et al. 2012).

Warmer temperatures will likely increase consumption by herbivores faster than increasing rates of NPP, strengthening top-down control on phytoplankton $\left(\mathrm{O}^{\prime}\right.$ Connor et al. 2009, Lewandowska \& Sommer 2010, Paul et al. 2015). Zooplankton grazing, while not directly accounted for in the model, is included in the aggregated formulation for pelagic heterotrophic consumption and could potentially be important in terminating spring blooms under warmer climate conditions, as warmer winter temperatures may allow these species to grow faster and reproduce earlier in the season (Oviatt 2004, Sommer \& Lewandowska 2011). Warmer winter temperatures could have an even more complex effect on top-down predation, as species such as copepods, ctenophores, and finfish that are normally relatively inactive during cooler winters could instead remain active preying on eggs, larvae, and zooplankton, or warmer water species could extend their range and seasonal distribution (Keller \& Klein-MacPhee 2000, Sullivan et al. 2001, Oviatt 2004, Harley et al. 2006, Mackas et al. 2007, Doney et al. 2012, George et al. 2015).
Model simulations indicated that relatively more organic material will be fixed into phytoplankton biomass in the upper YRE and subsequently advected down-estuary under warmer temperatures, while less phytoplankton biomass will be produced in the lower YRE. The water column and benthic communities in both of these regions will likely be affected by this change in NPP. A reduction of organic matter reaching the benthos may reduce benthic metabolism, nutrient regeneration, and alter whether the sediments act as a net source or sink of nitrogen to the overlying water column (Fulweiler et al. 2007, Nixon et al. 2009, Fulweiler \& Heiss 2014). Warmer mean winter temperatures have been directly correlated with lower mean monthly phytoplankton bloom biomass in other coastal systems (Oviatt et al. 2002), potentially supplying less organic matter to higher trophic levels, specifically benthic detritivores that rely on organic carbon deposited during intense blooms (Nixon et al. 2009). Indeed, phytoplankton primary production appears to be tightly linked to macrobenthic biomass in cross-system comparisons (Herman et al. 1999, Hagy 2002, Kemp et al. 2005). Additionally, changes in phytoplankton bloom communities to smaller, less-nutritious species have been suggested as a factor reducing bivalve growth and reproductive rates (Tracey et al. 1988). 

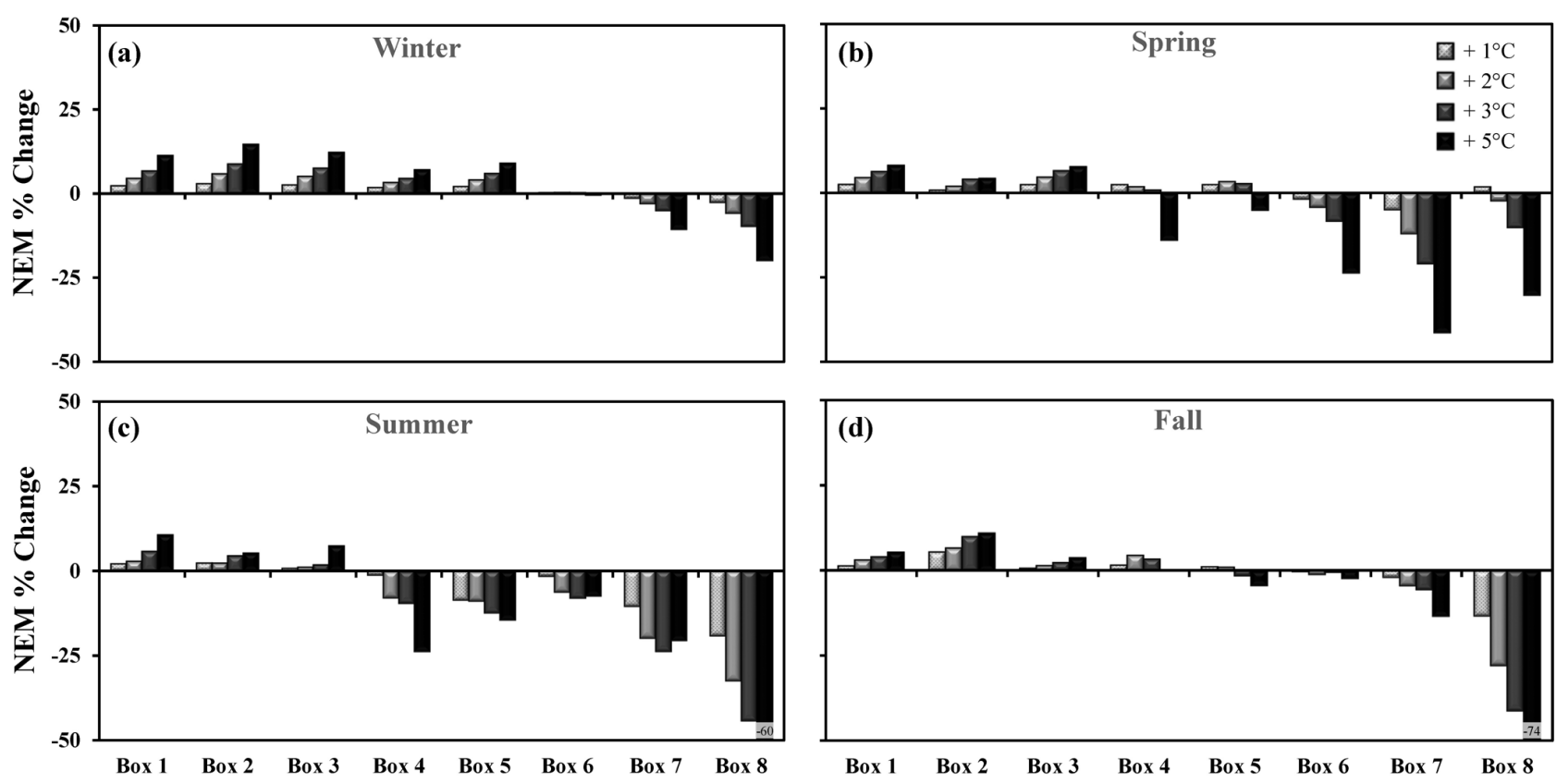

Fig. 6. Modeled percent change in net ecosystem metabolism (NEM) relative to the baseline model simulation, under a series of scenarios with increasing temperatures. Results were averaged over the 4 -yr simulation

\section{Changes in NEM}

When predicted changes in phytoplankton NPP were combined with simulated MPB production and water column and sediment respiration, results indicated an increase in NEM under warmer tempera- tures in the upper estuary throughout the year, while NEM in the lower estuary decreased (Fig. 6, Table 3). The percent reductions in NEM in the lower estuary do not necessarily indicate that NEM became heterotrophic. This was the case during limited time periods in some boxes, but on a seasonal basis the effect

Table 3. Modeled estimates of net ecosystem metabolism for 4 regions in the York River Estuary. Seasonal means and ranges (parentheses) are in $\mathrm{g} \mathrm{C} \mathrm{m}^{-2} \mathrm{~d}^{-1}$. Seasonal values are reported for winter (December to February), spring (March to May), summer (June to August) and fall (September to November). CC: current conditions

\begin{tabular}{|clllllllllll}
\hline & & \multicolumn{2}{c}{ Oligohaline } & \multicolumn{2}{c}{ Low mesohaline } & \multicolumn{2}{l}{ High mesohaline } & Polyhaline \\
\hline $\mathrm{CC}$ & Winter & 0.07 & $(-0.12-0.30)$ & 0.19 & $(-0.16-0.63)$ & 0.21 & $(-0.17-0.69)$ & 0.18 & $(-0.34-0.61)$ \\
& Spring & 0.18 & $(-0.14-0.94)$ & 0.38 & $(-0.55-2.11)$ & 0.40 & $(-0.59-1.99)$ & 0.44 & $(-1.13-2.23)$ \\
& Summer & 0.32 & $(-0.24-1.11)$ & 0.38 & $(-0.71-1.83)$ & 0.40 & $(-0.94-1.68)$ & 0.29 & $(-1.74-2.03)$ \\
& Fall & 0.18 & $(-0.35-0.89)$ & 0.29 & $(-0.26-0.65)$ & 0.32 & $(-0.31-0.97)$ & 0.19 & $(-0.67-0.69)$ \\
$+1^{\circ} \mathrm{C}$ & Winter & 0.07 & $(-0.13-0.32)$ & 0.19 & $(-0.17-0.66)$ & 0.21 & $(-0.18-0.72)$ & 0.17 & $(-0.37-0.62)$ \\
& Spring & 0.18 & $(-0.15-0.93)$ & 0.39 & $(-0.60-2.16)$ & 0.41 & $(-0.66-2.11)$ & 0.44 & $(-1.24-2.30)$ \\
& Summer & 0.33 & $(-0.27-1.23)$ & 0.38 & $(-0.85-1.97)$ & 0.38 & $(-1.13-1.63)$ & 0.24 & $(-1.97-1.92)$ \\
& Fall & 0.18 & $(-0.39-1.00)$ & 0.29 & $(-0.25-0.68)$ & 0.32 & $(-0.37-1.01)$ & 0.17 & $(-0.69-0.65)$ \\
$+2^{\circ} \mathrm{C}$ & Winter & 0.07 & $(-0.14-0.34)$ & 0.19 & $(-0.19-0.69)$ & 0.21 & $(-0.19-0.75)$ & 0.17 & $(-0.41-0.63)$ \\
& Spring & 0.18 & $(-0.17-1.11)$ & 0.40 & $(-0.66-2.04)$ & 0.40 & $(-0.72-1.97)$ & 0.41 & $(-1.35-2.11)$ \\
& Summer & 0.33 & $(-0.31-1.22)$ & 0.37 & $(-1.00-1.73)$ & 0.37 & $(-1.38-1.58)$ & 0.21 & $(-2.22-1.89)$ \\
& Fall & 0.19 & $(-0.44-0.96)$ & 0.30 & $(-0.26-0.71)$ & 0.32 & $(-0.35-1.06)$ & 0.16 & $(-0.74-0.61)$ \\
$+3^{\circ} \mathrm{C}$ & Winter & 0.08 & $(-0.16-0.36)$ & 0.20 & $(-0.21-0.73)$ & 0.22 & $(-0.20-0.79)$ & 0.16 & $(-0.45-0.63)$ \\
& Spring & 0.19 & $(-0.18-1.19)$ & 0.40 & $(-0.72-2.34)$ & 0.39 & $(-0.78-2.14)$ & 0.38 & $(-1.46-1.93)$ \\
& Summer & 0.34 & $(-0.34-1.25)$ & 0.37 & $(-1.17-2.18)$ & 0.36 & $(-1.61-1.90)$ & 0.19 & $(-2.38-2.07)$ \\
& Fall & 0.19 & $(-0.49-0.91)$ & 0.30 & $(-0.24-0.71)$ & 0.31 & $(-0.40-1.04)$ & 0.15 & $(-0.74-0.58)$ \\
$+5^{\circ} \mathrm{C}$ & Winter & 0.08 & $(-0.20-0.41)$ & 0.20 & $(-0.26-0.80)$ & 0.22 & $(-0.22-0.86)$ & 0.15 & $(-0.53-0.65)$ \\
& Spring & 0.19 & $(-0.20-1.25)$ & 0.38 & $(-0.85-1.76)$ & 0.35 & $(-0.90-1.99)$ & 0.29 & $(-1.70-1.72)$ \\
& Summer & 0.35 & $(-0.42-1.74)$ & 0.36 & $(-1.26-2.26)$ & 0.35 & $(-1.47-1.96)$ & 0.18 & $(-1.91-1.69)$ \\
& Fall & 0.19 & $(-0.56-0.86)$ & 0.29 & $(-0.34-0.75)$ & 0.31 & $(-0.53-0.96)$ & 0.12 & $(-0.83-0.49)$ \\
\hline
\end{tabular}


of warming was to reduce the degree of autotrophy rather than change the metabolic status (Table 3).

Throughout all 4 seasons, increasing rates of primary production (both water column and benthic) offset increasing rates of respiration in Boxes 1-3, resulting in an increase in NEM (Fig. 6). A portion of this autochthonous organic matter as well as allochthonous material from the upland watershed is flushed out of this region before it is respired. This increased autotrophy under warmer temperatures will supply additional labile organic matter to the rest of the estuary and potentially the lower CB. The biogeochemical processing of this additional organic material under warmer summer temperatures may act to fuel oxygen consumption in the middle portion of the estuary, which does not presently experience hypoxia, or worsen hypoxia in the lower estuary.

During the spring, Boxes 4 and 5 displayed month-to-month variations in simulated NEM, with changes relative to current conditions resulting from increased primary production within these boxes, elevated rates of respiration, and the advection of labile organic matter from both up-estuary boxes and CB. The latter has been shown to be an important source of organic material, leading to reduced oxygen concentrations in this system (Lake \& Brush 2015). Predicted NEM in this region of the estuary decreased in the summer due to decreasing phytoplankton NPP and increasing respiration rates with warming temperatures (Fig. 5c). Rates remained relatively constant with increasing temperatures throughout the fall (Fig. 6d).

While phytoplankton NPP during the winter months was predicted to increase in the polyhaline YRE (Boxes 7 and 8), the relatively higher rates of predicted respiration were more than enough to offset this increase in production under warmer temperature simulations (Fig. 6a). This trend of decreasing NEM with increasing temperatures was fairly consistent for the lower estuary throughout the spring, summer, and fall (Fig. $6 b-d$, Table 3). This is due to 4 factors: generally lower rates of phytoplankton NPP (Fig. 5b-d, Table 2); relatively lower surface area to volume ratios within this region due to a deeper channel (Table 1); higher rates of organic matter loading from up-estuary and especially the lower $\mathrm{CB}$, which provides an allochthonous substrate for respiration (Lake \& Brush 2015); and higher rates of water column and sediment respiration with increasing temperatures. Once again, these decreases in NEM reflect less autotrophy rather than a switch to heterotrophy (Table 3 ). This ecosystem shift in NEM in the lower estuary reinforces predictions from recent studies indicating that heterotrophic metabolism is more sensitive to changing temperatures than autotrophic production (López-Urrutia et al. 2006, O'Connor et al. 2009, Yvon-Durocher et al. 2010).

\section{Effect of a warmer climate on hypoxia}

Warmer temperatures were predicted to increase not only the predicted number of hypoxic $\left(<2 \mathrm{mg} \mathrm{O}_{2}\right.$ $\mathrm{l}^{-1}$ ) and low oxygen $\left(<3 \mathrm{mg} \mathrm{O}_{2} \mathrm{l}^{-1}\right)$ days in the upper and lower YRE, but also the spatial extent (i.e. the number of boxes) of low oxygen (Fig. 7). However, the effect of warmer temperatures was not equal in the upper and lower estuary. The effect of warming in the lower Mattaponi and Pamunkey Rivers (Boxes 1 and 2) was relatively monotonic, with a $1 \mathrm{~d}$ increase in hypoxia for each $1^{\circ} \mathrm{C}$ increase in temperature, while the number of hypoxic days in the lower estuary (Boxes 6-8) increased at a faster rate with warming. Little hypoxia was predicted in the middle estuary (Boxes 4 and 5) even under warming.
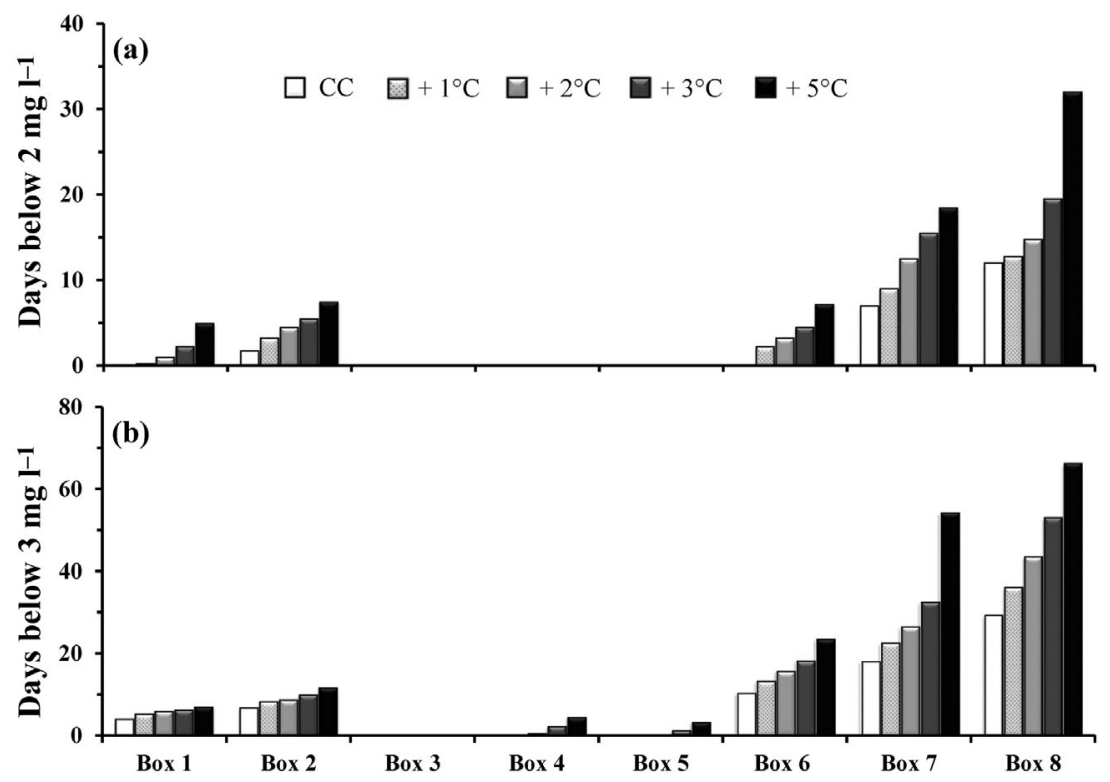

Fig. 7. Predicted annual number of (a) hypoxic $\left(<2 \mathrm{mg} \mathrm{O}_{2} \mathrm{l}^{-1}\right)$ and (b) low oxygen $\left(<3 \mathrm{mg} \mathrm{O}_{2} \mathrm{l}^{-1}\right)$ days within each model box under a range of temperature scenarios. Values represent the average number of days over the 4 -yr simulation. CC: current conditions 
The increase in hypoxia in the lower Mattaponi and Pamunkey Rivers under warming scenarios is a result of the high input of watershed-derived organic matter and elevated metabolic rates, combined with elevated phytoplankton biomass and NPP during the spring and early summer (AprilJune). This period is when the model predicted the development of low oxygen and hypoxia in the bottom water. A portion of this additional biomass is respired in the tributaries, reducing DO concentrations, before this labile organic matter is transported downstream. While this study did not focus on physical factors that may influence this process, it is likely that strong tidal and wind mixing, along with high river discharge, may alter this relationship as the surface and bottom water are mixed more thoroughly, or as material is flushed out of the region more quickly (Shen \& Haas 2004).

The middle portion of the estuary (Boxes 4 and 5) did not reach hypoxic conditions during any of the warming simulations. This is due in part to the extensive shoals, higher surface area to volume ratio, and relatively shallow depths in this region (Table 1), which make it subject to stronger tidal and wind mixing. Additionally, this region experiences lower water column and sediment respiration rates compared to the lower estuary (Lake et al. 2013). However, the greatest temperature increases $(+3$ and $+5^{\circ} \mathrm{C}$ ) were enough to produce low oxygen conditions in Boxes 4 and 5 (Fig. 7B). The boundary between the middle and lower regions of the estuary was a transition zone, where hypoxia developed in Box 6 under warmer temperature scenarios; however, oxygen concentrations in Box 5 remained above $2 \mathrm{mg} \mathrm{O}_{2} \mathrm{l}^{-1}$ throughout all simulations (Fig. 7a).

The lower estuary (Boxes 6-8) represents the most hypoxia-susceptible region of the system under current conditions, as well as warmer climate conditions (Fig. 7), due to a variety of factors. First, this region is directly influenced by advection of labile organic matter from the lower mainstem $\mathrm{CB}$, which has been shown to be a major driver of hypoxia in this region (Lake \& Brush 2015). Secondly, the enhanced production of organic matter in the upper estuary under warmer climate scenarios was largely advected downstream and respired in the middle and lower YRE. Third, under warmer temperatures, heterotrophic respiration in this region was predicted to increase faster than autotrophic production, resulting in greater consumption of this labile organic material and consequent reductions in oxygen concentrations. Finally, this region is represents the deepest portion of the estuary (Table 1), which has been shown to be partic- ularly susceptible to density-driven stratification and hypoxia during neap tides (Haas 1977, Kuo \& Neilson 1987, Sharples et al. 1994, Lake et al. 2013).

\section{Management scenarios under a warmer climate}

The US EPA recently developed total maximum daily loads (TMDLs) for the entire $C B$, including each tributary (US EPA 2010). Overall, the CB TMDL calls for reductions in total watershed loads of nitrogen and phosphorus by 25 and $24 \%$, respectively, based on modeled 2010 estimated loads (Linker et al. 2013). The TMDL calls for reductions in YRE watershed loads of nitrogen and phosphorus by 13 and $16 \%$, respectively. Our previous model analysis indicated that under current conditions, reducing watershed nutrient loading alone would be insufficient to eliminate hypoxia from the YRE (Lake \& Brush 2015). However, reducing watershed loads of both nutrients and organic matter by $15 \%$ would eliminate hypoxia within Boxes 1-3 (Lake \& Brush 2015). The current analysis corroborates this finding at a given temperature, but illustrates that for a given level of loading, the number of hypoxic days under elevated temperatures was often greater than that under current temperatures (Fig. 8). This finding indicates that greater tributary and watershed load reductions will be required to reduce hypoxia in this region of the YRE under a warmer climate, compared to reductions that would be required under current climate conditions (Fig. 9a,c).

Our previous analysis also indicated that the development of hypoxia in the polyhaline YRE is strongly influenced by the supply of nutrient- and organic-rich water advected from the lower CB via estuarine circulation (Lake \& Brush 2015). As above, reductions in these inputs at a given temperature resulted in an improvement in hypoxia in the current analysis; however, the resulting number of annual hypoxic days under warmer temperatures was in many cases greater than that under current temperatures (Fig. 10). Even if loads of nutrients, phytoplankton biomass, and organic matter (DOC and POC) entering from the $\mathrm{CB}$ are reduced by $25 \%$ of their current concentrations, the model simulations indicated that the YRE would still develop hypoxia in the lower estuary with a $2{ }^{\circ} \mathrm{C}$ increase in temperature, which is projected to occur between 2040 and 2069 (Najjar et al. 2009). This finding again demonstrates that greater load reductions will be required to offset hypoxia under a warmer climate compared to reductions required under current climate conditions (Fig. 9b,d). 

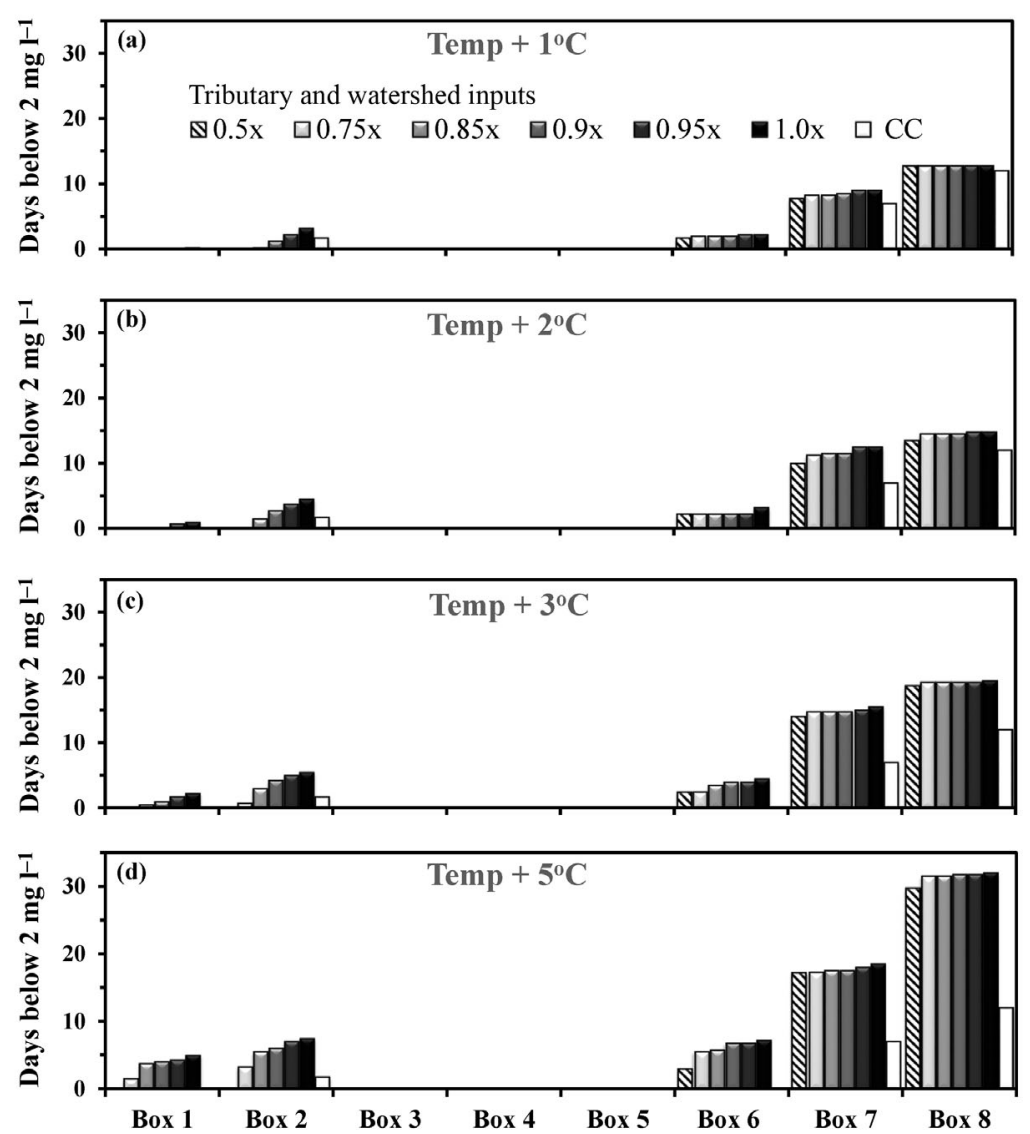

Fig. 8. Predicted annual number of hypoxic $\left(<2 \mathrm{mg} \mathrm{O}_{2} \mathrm{l}^{-1}\right)$ days within each box under various scenarios in which nutrient and organic matter (dissolved and particulate) loads from the tributaries and ungauged watersheds were reduced. Scenarios were run under current conditions (CC) and load reductions $(0.5 \times, 0.75 \times, 0.85 \times, 0.90 \times, 0.95 \times$, and $1.0 \times)$ under increasing temperatures of: (a) +1 , (b) +2 , (c) +3 , and $(\mathrm{d})+5^{\circ} \mathrm{C}$. Values represent the average number of days over the 4 -yr simulation

\section{Future climate change}

While this analysis focused solely on the effect of increased temperature on ecosystem function and hypoxia, it is important to note that these changes will be confounded by regional changes in precipitation, which ultimately control the input of freshwater, nitrogen, phosphorus, sediments, and organic matter from the surrounding watershed (Najjar et al. 2010, Altieri \& Gedan 2015). Seasonal changes in precipitation, evaporation, and flow regimes have the potential to alter the temporal and spatial extent of water column stratification and hypoxia (Bruce et al. 2014), and influence light availability and biotic resources (Buzzelli et al. 2014). Hagy (2002) and Kemp et al. (2005) illustrated the tightly coupled relationship between higher river flow (January to May) from the Susquehanna River and the volume of hy- poxia and anoxia in the mainstem CB. Future climate model predictions indicate that precipitation for the $\mathrm{CB}$ watershed could increase annually by 3,7 , and $9 \%$ above the 1971-2000 period between 2010-2039, 2040-2069, and 2070-2099, respectively (Najjar et al. 2009). While the seasonal timing of this increase in precipitation will determine how this additional freshwater will contribute to hypoxia in the Bay and its tributaries, it will likely lead to greater stratification, increased watershed loading of nutrients and organic matter, and enhanced estuarine circulation, thereby advecting more organic matter into the tributaries. These factors will likely fuel greater production and higher respiration rates, contributing to increases in the frequency, severity, and spatial extent of hypoxia. Wind forcing has also been identified as an important mechanism influencing hypoxia in the $\mathrm{CB}$ (Scully 2010); if summertime winds increase as a result of climate change (due to increasing storm activity or regional atmospheric patterns), enhanced physical mixing of the system could counteract other climatic effects driving hypoxia, such as elevated temperatures. Additional climate-related changes may also affect ecosystem function and hypoxia, including atmospheric composition (in particular $\mathrm{CO}_{2}$ concentrations), elevated sea level rise, increased storminess, changes in planktonic community composition, and loss of important habitat (e.g. seagrass and marshes) (Najjar et al. 2009, Doney et al. 2012). A more complete understanding of how these complex climatic changes will interact with ongoing watershed load reductions to shape the future state of estuaries is needed. Developing this understanding will require additional studies focused on both individual stressors as well as multiple factors acting in combination.

\section{CONCLUSIONS}

Estuarine response to warming will likely result in both spatial and temporal changes in water column primary production, NEM, and hypoxia. While this study focused solely on warmer temperatures, several broad trends emerged from this study, including: 

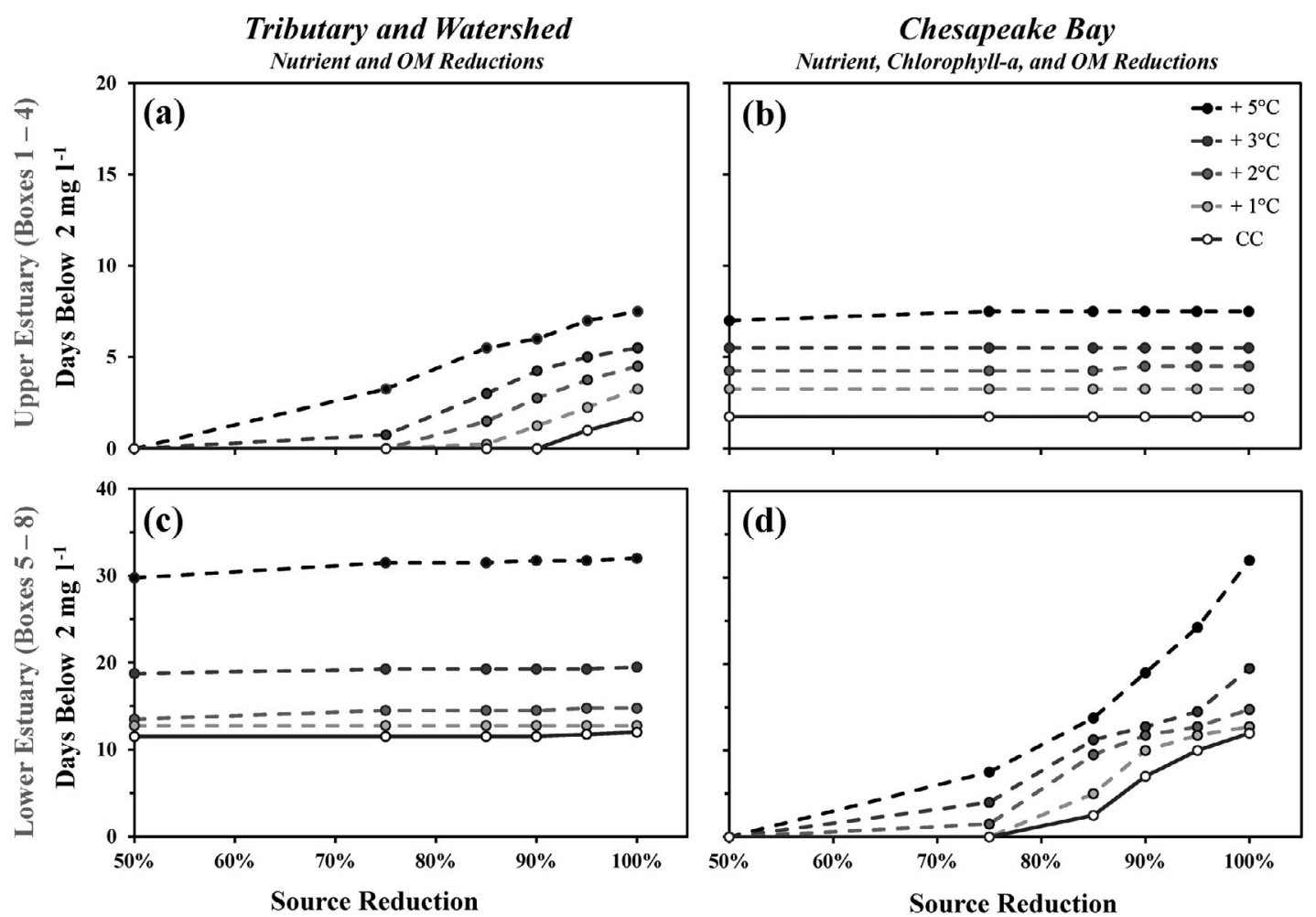

Fig. 9. Predicted maximum annual number of hypoxic $\left(<2 \mathrm{mg} \mathrm{O}_{2} \mathrm{l}^{-1}\right)$ days within the upper (Boxes 1-4 combined) and lower (Boxes 5-8 combined) York River Estuary, under a range of temperature warming scenarios $\left(+1,+2,+3\right.$, and $\left.+5^{\circ} \mathrm{C}\right)$ and external load reductions. $(\mathrm{a}, \mathrm{c})$ Effect of nutrient and organic matter reduction scenarios from the tributaries and ungauged watersheds in the (a) upper and (c) lower estuary. (b,d) Effect of nutrient, phytoplankton biomass, and organic matter reduction scenarios from Chesapeake Bay in the (b) upper and (d) lower estuary. Values represent the average number of hypoxic days over the 4-yr simulation. Source reductions were run under current conditions (CC) as well as 5\%,10\%, $15 \%, 25 \%$, and $50 \%$ reductions $(0.95 \times$, $0.90 \times, 0.85 \times, 0.75 \times$, and $0.50 \times$, respectively)

Fig. 10. Predicted annual number of hypoxic $\left(<2 \mathrm{mg} \mathrm{O}_{2} \mathrm{l}^{-1}\right)$ days within each box under various scenarios in which nutrients, phytoplankton biomass (calculated using chlorophyll a as a proxy), and organic matter (dissolved and particulate) loads from Chesapeake Bay were reduced. Scenarios were run under current conditions (CC) and load reductions $(0.5 \times, 0.75 \times, 0.85 \times, 0.90 \times$, $0.95 \times$, and $1.0 \times$ ) under increasing temperatures of: (a) +1 , (b) +2 , (c) +3 , and $(d)+5^{\circ} \mathrm{C}$. Values represent the average number of days over the 4 -yr simulation
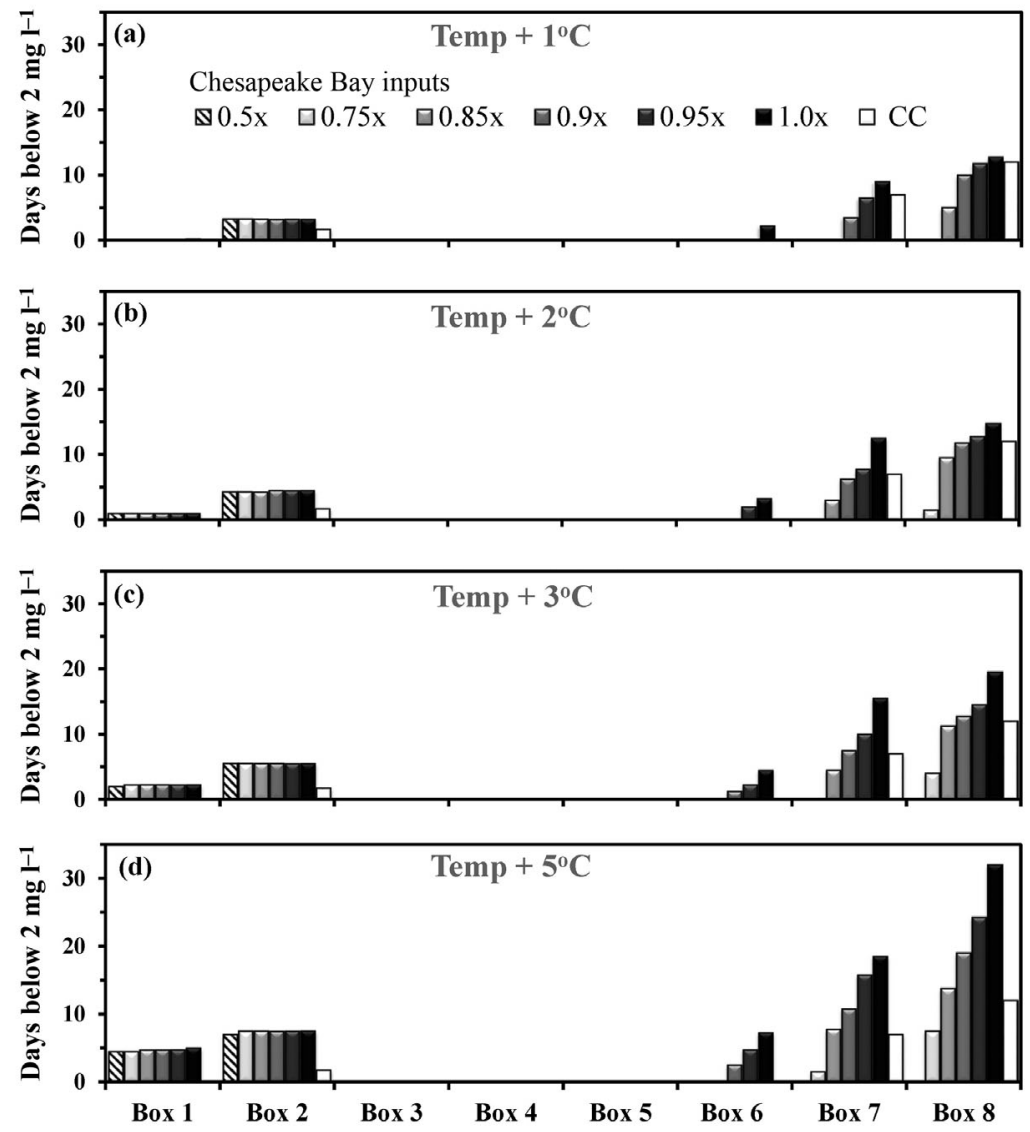
(1) Phytoplankton primary production was predicted to respond positively to warming during winter and spring. The response varied during summer and fall, with increased rates in the upper estuary and decreased rates in the middle and lower estuary.

(2) Model simulations indicated a temporal shift in maximum spring phytoplankton primary production and biomass, where blooms began 2 wk earlier under elevated temperatures.

(3) Warmer water temperatures led to increased NEM in the upper estuary as production was enhanced relative to respiration, but decreased NEM in the lower estuary due to decreased productivity and increased respiration, particularly of labile organic matter advected from upstream and the CB.

(4) Overall, warming was predicted to increase the number of hypoxic days in the upper and lower estuary, while the middle portion of the system remained relatively free of hypoxia. The effect was most pronounced in the lower estuary, which receives inputs of organic matter from upstream and CB.

(5) Model simulations suggest that warming will require additional load reductions beyond those required to mitigate hypoxia in the absence of warming. This response will be further complicated by other aspects of climate change, including precipitation, storminess, and sea level rise.

Acknowledgements. This project was partially funded by grants from the NOAA/UNH Cooperative Institute for Coastal and Estuarine Environmental Technology (NA05 NOS4191149) and the NOAA Coastal Hypoxia Research Program (CHRP) (NA05NOS4781201, NA11NOS4780043). S.J.L. also received financial support from NSF GK-12 (Division of Graduate Education 0840804). We thank W. Michael Kemp and three anonymous reviewers for their input. We also thank Larry Haas, Jennifer Stanhope, Hunter Walker, Lisa Ott, Juliette Giordano, and many other VIMS students and staff members for their field and laboratory assistance. This is NOAA CHRP contribution no. 204 and Virginia Institute of Marine Science contribution no. 3489.

\section{LITERATURE CITED}

Altieri AH, Gedan KB (2015) Climate change and dead zones. Glob Change Biol 21:1395-1406

> Boesch DF (2002) Challenges and opportunities for science in reducing nutrient over-enrichment of coastal ecosystems. Estuaries 25:886-900

> Boynton WR, Garber JH, Summers R, Kemp WM (1995) Inputs, transformations, and transport of nitrogen and phosphorus in Chesapeake Bay and selected tributaries. Estuaries 18:285-314

Boynton WR, Hagy JD, Cornwell JC, Kemp WM and others (2008) Nutrient budgets and management actions in the Patuxent River estuary, Maryland. Estuaries Coasts 31: 623-651
Bruce LC, Cook PLM, Teakle I, Hipsey MR (2014) Hydrodynamic controls on oxygen dynamics in a riverine salt wedge estuary, the Yarra River estuary, Australia. Hydrol Earth Syst Sci 18:1397-1411

Brush MJ (2002) Development of a numerical model for shallow marine ecosystems with application to Greenwich Bay, R.I. PhD Dissertation, University of Rhode Island, Kingston, RI

Brush MJ (2004) Application of the Greenwich Bay ecosystem model to the development of the Greenwich Bay SAMP (Special Area Management Plan). Final Report to Rhode Island Coastal Resources Center, University of Rhode Island, Narragansett, RI

Brush GS (2009) Historical land use, nitrogen, and coastal eutrophication: a paleoecological perspective. Estuaries Coasts 32:18-28

Brush MJ, Brawley JW (2009) Adapting the light·biomass (BZI) models of phytoplankton primary production to shallow marine ecosystems. J Mar Syst 75:227-235

> Brush GS, Davis FW (1984) Stratigraphic evidence of human disturbance in an estuary. Quat Res 22:91-108

Brush MJ, Brawley JW, Nixon SW, Kremer JN (2002) Modeling phytoplankton production: problems with the Eppley curve and an empirical alternative. Mar Ecol Prog Ser 238:31-45

Buzzelli C, Doering P, Wan Y, Sun D (2014) Modeling ecosystem processes with variable freshwater inflow to the Caloosahatchee River Estuary, southwest Florida. II. Nutrient loading, submarine light, and seagrasses. Estuar Coast Shelf Sci 151:272-284

Caffrey JM (2004) Factors controlling net ecosystem metabolism in US estuaries. Estuaries 27:90-101

> Canuel EA, Cammer SS, McIntosh HA, Pondell CR (2012) Climate change impacts on the organic carbon cycle at the land-ocean interface. Annu Rev Earth Planet Sci 40:685-711

> Cloern JE (2001) Our evolving conceptual model of the coastal eutrophication problem. Mar Ecol Prog Ser 210: 223-253

> Cloern JE, Jassby AD (2008) Complex seasonal patterns of primary producers at the land-sea interface. Ecol Lett 11:1294-1303

> Cloern JE, Knowles N, Brown LR, Cayan D and others (2011) Projected evolution of California's San Francisco BayDelta-River system in a century of climate change. PLoS ONE 6:e24465

> Cooper SR, Brush GS (1993) A 2,500-year history of anoxia and eutrophication in Chesapeake Bay. Estuaries 16: $617-626$

> Cornwell JC, Owens MS (2011) Quantifying sediment nitrogen releases associated with estuarine dredging. Aquat Geochem 17:499-517

> Cowan JLW, Boynton WR (1996) Sediment-water oxygen and nutrient exchanges along the longitudinal axis of Chesapeake Bay: seasonal patterns, controlling factors and ecological significance. Estuaries 19:562-580

de Jonge VN, Boynton W, D'Elia CF, Elmgren R, Welsh RL (1994) Responses to developments in eutrophication in four different North Atlantic estuarine systems. Olsen \& Olsen, Fredensborg, p 179-196

> Doney SC, Ruckelshaus M, Duffy JE, Barry JP and others (2012) Climate change impacts on marine ecosystems. Annu Rev Mar Sci 4:11-37

> Dynesius M, Nilsson C (1994) Fragmentation and flow regulation of river systems in the northern third of the world. 
Science 266:753-762

Edwards M, Richardson AJ (2004) Impact of climate change on marine pelagic phenology and trophic mismatch. Nature 430:881-884

Fulweiler RW, Heiss EM (2014) (Nearly) a decade of directly measured sediment $\mathrm{N}_{2}$ fluxes. What can Narragansett Bay tell us about the global ocean nitrogen budget? Oceanography 27:184-195

Fulweiler RW, Nixon SW, Buckley BA, Granger SL (2007) Reversal of the net dinitrogen gas flux in coastal marine sediments. Nature 448:180-182

George JA, Lonsdale DJ, Merlo LR, Gobler CJ (2015) The interactive roles of temperature, nutrients, and zooplankton grazing in controlling the winter-spring phytoplankton bloom in a temperate, coastal ecosystem, Long Island Sound. Limnol Oceanogr 60:110-126

Gibson JR, Najjar RG (2000) The response of Chesapeake Bay salinity to climate-induced changes in streamflow. Limnol Oceanogr 45:1764-1772

Goldberg ED, Hodge V, Koide M, Griffin J and others (1978) A pollution history of Chesapeake Bay. Geochim Cosmochim Acta 42:1413-1425

> Haas LW (1977) The effect of the spring-neap tidal cycle on the vertical salinity structure of the James, York, and Rappahannock Rivers, Virginia, USA Estuar Coast Mar Sci 5:485-496

Hagy JD (2002) Eutrophication, hypoxia and trophic transfer efficiency in Chesapeake Bay. PhD Dissertation, University of Maryland, College Park, MD

> Harding LW, Mallonee ME, Perry ES (2002) Toward a predictive understanding of primary productivity in a temperate, partially stratified estuary. Estuar Coast Shelf Sci 55:437-463

Harley CDG, Hughes AR, Hultgren KM, Miner BG and others (2006) The impacts of climate change in coastal marine systems. Ecol Lett 9:228-241

Herman PMJ, Middelburg JJ, van de Koppel J, Heip CHR (1999) Ecology of estuarine macrobenthos. Adv Ecol Res 29:195-240

Hopkinson CS, Smith EM (2005) Estuarine respiration: an overview of benthic, pelagic, and whole system respiration. In: Del Giorgio PA, Williams PJleB (eds) Respiration in aquatic ecosystems. Oxford University Press, Oxford, p 122-146

Howarth RW, Marino R (2006) Nitrogen as the limiting nutrient for eutrophication in coastal marine ecosystems: evolving views over three decades. Limnol Oceanogr 51:364-376

IPCC (2007) Climate change 2007: Synthesis Report. In: Core Writing Team, Pachauri RK, Reisinger E (eds) Contribution of Working Groups I, II and III to the Fourth Assessment Report of the Intergovernmental Panel on Climate Change. IPCC, Geneva

Kana TM, Sullivan MB, Cornwell JC, Groszkowski KM (1998) Denitrification in estuarine sediments determined by membrane inlet mass spectrometry. Limnol Oceanogr 43:334-339

Kana TM, Cornwell JC, Zhong L (2006) Determination of denitrification in the Chesapeake Bay from measurements of $\mathrm{N}_{2}$ accumulation in bottom water. Estuaries Coasts 29:222-231

Keller AA, Klein-MacPhee G (2000) Impact of elevated temperature on the growth, survival, and trophic dynamics of winter flounder larvae: a mesocosm study. Can J Fish Aquat Sci 57:2382-2392
Kemp WM, Boynton WR, Adolf JE, Boesch DF and others (2005) Eutrophication of Chesapeake Bay: historical trends and ecological interactions. Mar Ecol Prog Ser 303: $1-29$

Kremer JN, Vaudrey JMP, Ullman DS, Bergondo DL and others (2010) Simulating property exchange in estuarine ecosystem models at ecologically appropriate scales. Ecol Modell 221:1080-1088

Kuo AY, Neilson BJ (1987) Hypoxia and salinity in Virginia estuaries. Estuaries 10:277-283

Kuo AY, Neilson BJ, Brubaker J Ruzecki. EP (1993) Data report: hypoxia in the York River, 1991. Virginia Inst Mar Sci Data Rep No 47. Gloucester Point, VA

> Lake SJ, Brush MJ (2015) Contribution of nutrient and organic matter sources to the development of periodic hypoxia in a tributary estuary. Estuaries Coasts 38: 2149-2171

> Lake SJ, Brush MJ, Anderson IC, Kator HI (2013) Internal versus external drivers of periodic hypoxia in a coastal plain tributary estuary: the York River, Virginia. Mar Ecol Prog Ser 492:21-39

Levitus S, Antonov JI, Boyer TP, Stephens C (2000) Warming of the world ocean. Science 287:2225-2229

Lewandowska A, Sommer U (2010) Climate change and the spring bloom: a mesocosm study on the influence of light and temperature on phytoplankton and mesozooplankton. Mar Ecol Prog Ser 405:101-111

Linker LC, Batiuk RA, Shenk GW, Cerco CF (2013) Development of the Chesapeake Bay watershed total maximum daily load allocation. J Am Water Resour Assoc 49: 986-1006

López-Urrutia A, San Martin E, Harris RP, Irigoien X (2006) Scaling the metabolic balance of the oceans. Proc Natl Acad Sci USA 103:8739-8744

Lotze HK (2010) Historical reconstruction of human-induced changes in US estuaries. Oceanogr Mar Biol Annu Rev 48:267-338

> Mackas DL, Batten S, Trudel M (2007) Effects on zooplankton of a warmer ocean: recent evidence from the Northeast Pacific. Prog Oceanogr 75:223-252

Meier HEM, Andersson HC, Eilola K, Gustafsson BG and others (2011) Hypoxia in future climates: a model ensemble study for the Baltic Sea. Geophys Res Lett 38:L24608

Meier HEM, Müller-Karulis B, Andersson HC, Dieterich C and others (2012) Impact of climate change on ecological quality indicators and biogeochemical fluxes in the Baltic Sea: a multi-model ensemble study. Ambio 41:558-573

> Ménesguen A, Cugier P, Loyer S, Vanhoutte-Brunier A, Hoch T, Guillaud JF, Gohin F (2007) Two- or threelayered box-models versus fine 3D models for coastal ecological modelling? A comparative study in the English Channel (Western Europe). J Mar Syst 64:47-65

> Moss B, Kosten S, Meerhof M, Battarbee R and others (2011) Allied attack: climate change and eutrophication. Inland Waters 1:101-105

> Murdoch PS, Baron JS, Miller TL (2000) Potential effects of climate change on surface-water quality in North America. J Am Water Resour Assoc 36:347-366

Najjar R, Patterson L, Graham S (2009) Climate simulations of major estuarine watersheds in the Mid-Atlantic region of the US. Clim Change 95:139-168

Najjar RG, Pyke CR, Adams MB, Breitburg D and others (2010) Potential climate-change impacts on the Chesapeake Bay. Estuar Coast Shelf Sci 86:1-20

Neumann T, Eilola K, Gustafsson B, Müller-Karulis B, 
Kuznetsov I, Meier HEM, Savchuk OP (2012) Extremes of temperature, oxygen and blooms in the Baltic Sea in a changing climate. Ambio 41:574-585

Nixon SW (1986) Nutrient dynamics and the productivity of marine coastal waters. In: Halwagy R, Clayton D, Behbehani M (eds) Marine environment and pollution. The Alden Press, Oxford, p 97-115

Nixon SW (1995) Coastal marine eutrophication: a definition, social causes, and future concerns. Ophelia 41: 199-219

Nixon SW, Fulweiler RW, Buckley BA, Granger SL, Nowicki BL, Henry KM (2009) The impact of changing climate on phenology, productivity, and benthic-pelagic coupling in Narragansett Bay. Estuar Coast Shelf Sci 82:1-18

O'Connor MI, Piehler MF, Leech DM, Anton A, Bruno JF (2009) Warming and resource availability shift food web structure and metabolism. PLoS Biol 7:e1000178

Odum HT (1994) Ecological and general systems: an introduction to systems ecology, 2nd edn. University Press of Colorado, Niwot, CO

Officer CB (1980) Box models revisited. In: Hamilton P, MacDonald KB (eds) Estuarine and wetland processes with emphasis on modeling. Plenum Press, New York, p 65-114

Oviatt CA (2004) The changing ecology of temperate coastal waters during a warming trend. Estuaries 27:895-904

Oviatt C, Keller A, Reed L (2002) Annual primary production in Narragansett Bay with no bay-wide winter-spring phytoplankton bloom. Estuar Coast Shelf Sci 54:1013-1026

Paerl HW, Huisman J (2008) Blooms like it hot. Science 320:57-58

Paerl HW, Huisman J (2009) Climate change: a catalyst for global expansion of harmful cyanobacterial blooms. Environ Microbiol Rep 1:27-37

Paerl HW, Otten TG (2013) Harmful cyanobacterial blooms: causes, consequences, and controls. Microb Ecol 65: 995-1010

Paul C, Matthiessen B, Sommer U (2015) Warming, but not enhanced $\mathrm{CO}_{2}$ concentration, quantitatively and qualitatively affects phytoplankton biomass. Mar Ecol Prog Ser 528:39-51

Richardson K, Heilmann JP (1995) Primary production in the Kattegat: past and present. Ophelia 41:317-328

Scavia D, Field JC, Boesch DF, Buddemeier RW and others (2002) Climate change impacts on US coastal and marine ecosystems. Estuaries 25:149-164

Scully ME (2010) Wind modulation of dissolved oxygen in Chesapeake Bay. Estuaries Coasts 33:1164-1175
Sharples J, Simpson J, Brubaker J (1994) Observations and modelling of periodic stratification in the upper York River estuary, Virginia. Estuar Coast Shelf Sci 38: 301-312

> Shen J, Haas L (2004) Calculating age and residence time in the tidal York River using three-dimensional model experiments. Estuar Coast Shelf Sci 61:449-461

Smith EM, Kemp WM (1995) Seasonal and regional variations in plankton community production and respiration for Chesapeake Bay. Mar Ecol Prog Ser 116:217-231

Smith LM, Whitehouse S, Oviatt CA (2010) Impacts of climate change on Narragansett Bay. Northeast Nat 17: 77-90

> Sommer U, Lewandowska A (2011) Climate change and the phytoplankton spring bloom: warming and overwintering zooplankton have similar effects on phytoplankton. Glob Change Biol 17:154-162

Sullivan BK, Van Keuren D, Clancy M (2001) Timing and size of blooms of the ctenophore Mnemiopsis leidyi in relation to temperature in Narragansett Bay, RI. Hydrobiologia 451:113-120

Testa JM, Kemp WM (2008) Variability of biogeochemical processes and physical transport in a partially stratified estuary: a box-modeling analysis. Mar Ecol Prog Ser 356: 63-79

Testa JM, Kemp WM, Boynton WR, Hagy JD III (2008) Longterm changes in water quality and productivity in the Patuxent River Estuary: 1985 to 2003. Estuaries Coasts 31:1021-1037

Tracey GA, Johnson PW, Steele RW, Hargraves PE, Sieburth JM (1988) Shift in photosynthetic picoplankton composition and its effect on bivalve mollusc nutrition: the 1985 'brown tide' in Narragansett Bay, Rhode Island. J Shellfish Res 7:671-675

US EPA (2010) Chesapeake Bay total maximum daily load for nitrogen, phosphorus and sediment. Region III Chesapeake Bay Program Office, Annapolis, MD

Whitehead PG, Wilby RL, Battarbee RW, Kernan M, Wade AJ (2009) A review of the potential impacts of climate change on surface water quality. Hydrol Sci J 54:101-123

- Yvon-Durocher G, Jones JI, Trimmer M, Woodward G, Montoya JM (2010) Warming alters the metabolic balance of ecosystems. Philos Trans R Soc Lond B Biol Sci 365: 2117-2126

Zimmerman AR, Canuel EA (2000) A geochemical record of eutrophication and anoxia in Chesapeake Bay sediments: anthropogenic influence on organic matter composition. Mar Chem 69:117-137

Submitted: November 10, 2014; Accepted: August 4, 2015

Proofs received from author(s): October 13, 2015
Editorial responsibility: William Kemp,

Cambridge, Maryland, USA 